Petar Puhmajer

Hrvatski restauratorski zavod, Zagreb

Ratko Vučetić

Institut za povijest umjetnosti, Zagreb

Ivana Haničar Buljan

Institut za povijest umjetnosti, Zagreb

\title{
Građanska arhitektura 18. stoljeća u osječkoj Tvrđi: stambeno-trgovačke katnice
}

\author{
Izvorni znanstveni rad - Original scientific paper \\ Primljen - Received 1. 8. 2021. \\ UDK 728.1(1-21)](497.5Osijek)"17".
}

DOI https://doi.org/10.31664/ripu.2021.45.14

\begin{abstract}
Sažetak
U članku se razmatraju prostorne i oblikovne značajke stambene arhitekture Osijeka u 18. stoljeću. To su većinom građanske kuće obrtnika, trgovaca, gradskih i vojnih činovnika, koje nastaju na parcelama unutar planski izgrađenoga grada-tvrđave. Kuće imaju karakteristična tlocrtna obilježja koja čine nizovi i grupe prostorija, kod kvalitetnijih $u$ prizemlju redovito s vežom, koja može biti centrirana ili decentrirana u odnosu na središnju os, a na katu reprezentativni salon. Identificiraju se
\end{abstract}

pojedinačni primjeri kuća, sobzirom na vrijeme nastanka i naručitelje, kao i arhitektonska rješenja, uz bitnu odrednicu da je riječ mahom o reprezentativnim katnicama višeg standarda koje su se isticale u vizuri grada. One u izvjesnoj mjeri preuzimaju elemente s javnih $i$ vojnih zgrada što se tumači djelovanjem istih graditelja i projektanata - vojnih inženjera koji su bili angažirani na gradnji tvrdave, a koji dokumentirano projektiraju i građanske kuće.

Ključne riječi: arhitektura, stambena arhitektura, barokna arhitektura, Osijek, Tvrđa, kuće, prostorna organizacija, pročelja

Poznavanje arhitekture osječke Tvrđe ${ }^{1}$ posljednjih se desetljeća, istraživačkim naporima, znatno nadopunjuje novim podatcima. I dok je izgradnja tvrđave vrlo detaljno dokumentirana na brojnim projektima za vojne zgrade i bastione, građanske kuće 18. stoljeća u tom su smislu ostale u drugom planu. Čitanje prvotnih prostornih i oblikovnih karakteristika kuća ograničeno je stoga na proučavanje postojećeg stanja i sekundarne dokumentacije, poput nacrta i fotografija iz kasnijeg vremena, ili pak konzervatorskih sondi koje nude uvid u građevinske strukture. $U$ istraživanju su relevantni i planovi grada na kojima se vidi izgrađenost, dimenzije parcela, a nekad i tlocrtni oblici kuća. Pojedinačne kuće najranije su zabilježene na mađarskom planu Osijeka nazvanom Eszék-Vár iz 1733. godine, ${ }^{2}$ doduše samo shematski, ali su na njemu upisana imena vlasnika kuća. Vlasništvo se nakon toga može pratiti putem zapisa iz Zemljišne knjige grada Osijeka, nastale otprilike 1747./1748. te nadopunjavane tijekom druge polovine 18. i u 19. stoljeću. ${ }^{3}$ Utvrđivanje kronologije vlasnika pomaže u identificiranju prvotnih naručitelja, koji su, dakle, bili zaslužni za izvorni prostor i izgled kuća, ali isto tako i naručitelja većih obnova, dogradnji i preinaka u kasnijem razdoblju. U urbanističkom je pogledu najilustrativniji plan tvrđave Osijek iz 1828. godine (sl. 1) ${ }^{4}$ na kojemu je vidljiv "barokni" grad, s formiranim rasporedom ulica i prikazom pojedinačnih parcela i kuća, pretežito sagrađenih u 18. stoljeću. Osijek, dakako, pa ni sama Tvrđa, ne nastaje iznova, na ledini, nego na temeljima srednjovjekovnih i 


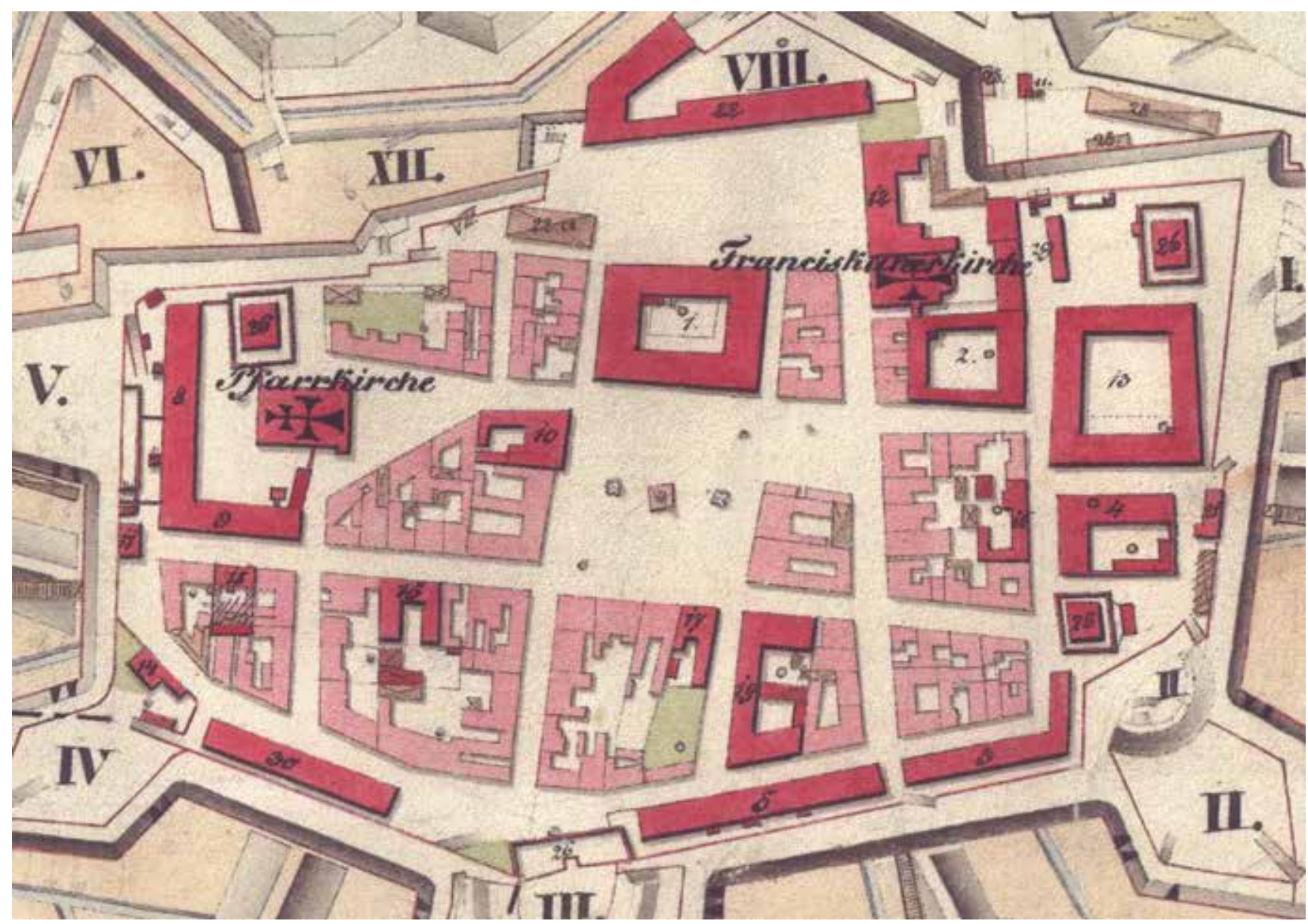

1. Plan tvrđave Osijek iz 1828. godine (ÖSTA-KA)

Map of the Osijek Fortress from 1828

osmanskih slojeva, ali će planiranje novoga grada-tvrđave uvelike odrediti njegov današnji izgled i stambeni fond.

\section{Urbanistički aspekti}

Prostorna struktura osmanskog Osijeka oslanjala se na zatečeno stanje srednjovjekovnog naselja, prilagodivši se novoj situaciji. Grad je bio formiran oko mahala organiziranih uz vjerske objekte. Prema opisima suvremenika koji su u Osijek dolazili s kršćanskog zapada tijekom 16. stoljeća, u gradu su prevladavale drvene kuće ili one građene od ćerpiča, prekrivene slamom ili šindrom. ${ }^{5}$ Do kraja 16. stoljeća pretpostavljen je broj od 100 do 200 kuća na prostoru kasabe, tj. današnje Tvrđe, što bi odgovaralo broju kuća srednjovjekovnog Osijeka. ${ }^{6}$ Tijekom 17. stoljeća zbog stabilnije situacije i porasta trgovačkog značenja grada, broj kuća se povećava, što dovodi do nestanka vrtova, tj. smanjenja okućnica. Prema opisima 17. stoljeća u kasabi, tj. utvrđenom gradu bilo je 400 kuća zidanih prizemnica i jednokatnica, pokrivenih šindrom, zgusnute gradnje bez vrtova. ${ }^{7}$ Nakon oslobođenja od osmanske vlasti 1687. godine, grad se našao pod komorskom upravom, a 1690. osnovano je i gradsko poglavarstvo. ${ }^{8}$ Tada nastaje i osnovni koncept planiranoga utvrđenoga gra- da, sa središnjim pravilnim trgom, sustavom vojarni uz rub fortifikacija i izgradnjom blokova unutar pravilnog rastera.

Transformacija grada odvijala se postupno, oslanjajući se na postojeću urbanu strukturu, zbog čega se u rasteru ulica zamjećuje niz odstupanja od pravilne prostorne sheme. U središtu grada oblikovan je glavni trg između dvije paralelne ulice pružanja istok - zapad. Usporedno s vojnim, razvijaju se i građanske funkcije, pa se u grad naseljava i civilno stanovništvo. Prema dostupnim podatcima 1698. godine unutar gradskih utvrda, na području današnje Tvrđe nalazile su se 53 kuće, a 1702. navodi se 90 kuća. ${ }^{9}$ Usporedimo li tadašnji broj kuća s brojem kuća osmanskoga grada u 17. stoljeću, očito se njihov broj bitno smanjio, vjerojatno zbog iseljavanja stanovnika, a rahla struktura izgradnje olakšala je planiranje nove urbane matrice ortogonalnoga "baroknog" grada i omogućila doseljavanje novog stanovništva, čiji broj se gotovo udvostručio u tek nekoliko godina. Kao i u prethodnom razdoblju, prvobitne kuće bile su drvene, a tek kasnije zamjenjuju se zidanicama. Prema dostupnim podatcima, navodno je prva stambena kuća u Tvrđi podignuta 1690. godine, nakon posljednjega osmanskog pokušaja osvajanja grada, nasuprot današnjem franjevačkom samostanu u Franjevačkoj ulici. ${ }^{10}$ 

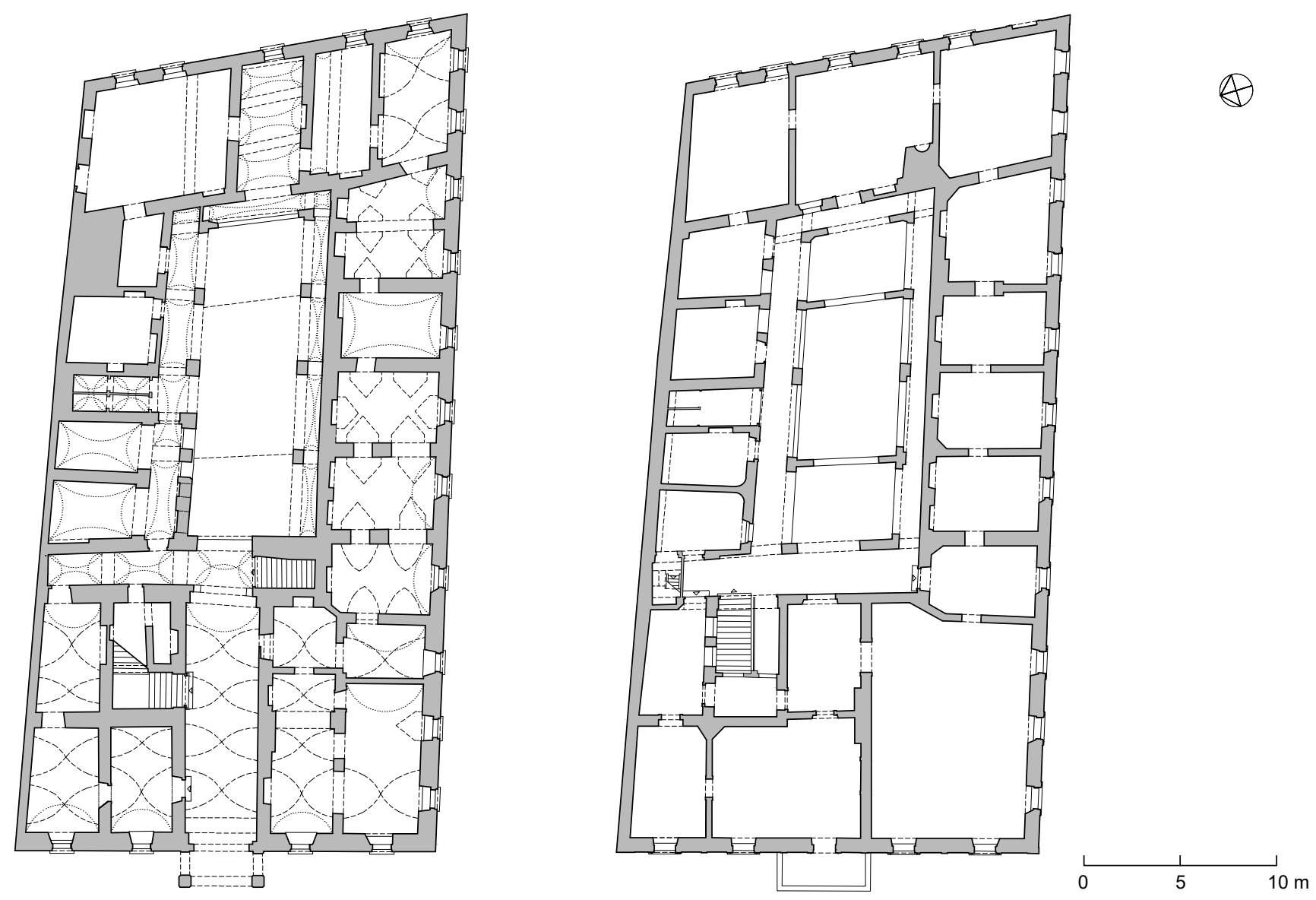

2. Zgrada gradskog magistrata (Trg sv. Trojstva 6), tlocrt prizemlja i kata (Planoteka IPU)

City Magistrate building (Trg sv. Trojstva 6), ground floor and first floor plans

Prostornu okosnicu čine srednjovjekovne komunikacije, današnja Kuhačeva ulica, glavna gradska ulica koja povezuje istočna i zapadna gradska vrata, a u smjeru sjever - jug $s$ Kuhačevom se križa druga prostorna okosnica, današnja Franjevačka ulica. Uz te dvije ulice i uza središnji gradski trg nastaju najreprezentativnije gradske kuće. Vlasnici tih kuća uglavnom su istaknuti trgovci, ponekad i plemstvo, pripadnici gradske elite. Prve se kuće podižu već krajem 17. stoljeća i one su mahom drvene, no nakon 1714. i obveze gradnje kuća u čvrstom materijalu, u sve većem broju zamjenjuju ih zidanice. Najveće parcele organizirane su uz južnu stranu Kuhačeve ulice, dok se u rubnim prostorima grada i u sekundarnim ulicama parcele smanjuju. Očito je južna strana Kuhačeve smatrana reprezentativnijom od sjeverne strane ulice, pa tu nastaju i najkvalitetnije građanske kuće.

Dimenzije parcela određuju i volumen kuća. Uz uličnu frontu, u regulacijskoj liniji ulice, u neprekinutom nizu kuće su postavljene dužom stranom, na većim parcelama uobičajeno s kolnim ulazom i pomoćnim, gospodarskim zgradama uz rub i u dnu parcele. U pravilu gradske kuće su jednokatnice s podrumima, strmog krovišta, pokrivenog crijepom, a prizemnice se grade u perifernim dijelovima grada, u većem broju uz ophodnu cestu, gdje nalazimo veći broj gostionica, te $\mathrm{u}$ istočnom dijelu grada koji ima sekundarno značenje. Jednokatne kuće na manjim parcelama u pravilu imaju ma- nje dvorište, bez kolnog ulaza, a može se zamijetiti i česta troosna podjela pročelja. Reprezentativne kuće uobičajeno su dvokrilne ili trokrilne, s krilima koja se pružaju rubom parcele, dekorativno obrađenih pročelja. Prestižni položaj u bloku imaju uglovnice, ponekad naglašene erkerima ili nišama sa skulpturama.

Kada Osijek 1809. stječe status slobodnoga kraljevskog grada, u prostoru Tvrđe zabilježeno je 110 kuća. ${ }^{11}$ Tijekom 18. stoljeća broj kuća varirao je između 90 i 110. S vremenom je dolazilo do promjena parcelacije i spajanja parcela u sporednim ulicama, no izgleda da je parcelacija uzduž glavne, Kuhačeve ulice uz manje izmjene zadržala prvobitnu, osnovnu strukturu parcelacije, dimenzija i pozicioniranja kuća formiranih u 18. stoljeću.

\section{Javne i vojne zgrade kao uzori za građanske kuće}

Poticaji za razvoj prostorno-organizacijskih rješenja kuća morali su doći gradnjom nekolicine većih javnih i vojnih zgrada u prvoj četvrtini 18. stoljeća, s obzirom na vrlo slične koncepte ostvarene, dakako, u većem mjerilu. Jedna od prvih koja se podiže nakon oslobođenja Gradski je magistrat (sl. 2 a, b), oko 1702 . godine, ${ }^{12}$ velika katnica koja zaprema polovinu gradskog bloka te omeđuje znatan dio istočne strane 
glavnog trga. Prvotno je sagrađeno samo glavno, zapadno krilo, prema trgu, u jednokatnoj visini te južno dvorišno krilo u razini prizemlja. U prilog tome govori i činjenica da je na glavnom krilu i danas zadržano krovište "na lastavicu", a južno ima dvostrešan krov. Sva su lateralna krila dograđena tek 1812. godine, no s ponavljanjem artikulacije glavnog krila. ${ }^{13}$ Tlocrt je određen osovinski smještenom vežom oko koje se formiraju dvije grupe od četiri prostorije. Raspored kata danas ne odgovara onom u prizemlju, čemu su možda razlog naknadne izmjene, no zamjetan je i izmak glavne dvorane u odnosu na središnju os, koja ovdje zaprema jugozapadni ugao kata, što je odraz tendencija 17. i početka 18. stoljeća u profanoj arhitekturi te bi, po svemu sudeći, mogla biti riječ o izvornoj situaciji.

Zgrada Glavne straže iz 1728. godine ${ }^{14} \mathrm{u}$ znatnoj mjeri ponavlja tlocrtnu shemu Magistrata, s prizemljem određenim ulaznim hodnikom, no ovdje su tek po dvije, poprečno položene dvorane bočno od njega, dok će grupe od po četiri prostorije s obje strane hodnika biti formirane na katu. Ondje je pak uočljiv izostanak središnje dvorane te na njenom mjestu pojava osovinski položenog hodnika koji vodi do uspona u toranj, što je posve razumljivo s obzirom na namjenu zgrade. Ovdje se dvorišna pročelja rastvaraju masivnim zidanim arkadama.

Palačom Slavonske Generalkomande (1723./1724.) ostvareno je novo rješenje koje se ne oslanja na uobičajene modele, nego uzore traži u znatno naprednijim sredinama, konkretno, u profanoj arhitekturi prijestolnice. ${ }^{15}$ Artikulacija veže koja je ovdje izvedena kao vestibul podijeljen masivnim stupovima na tri broda, po uzoru na bečke palače, dva monumentalna stubišta kojima se iz veže uspinje na kat, kao i arkadno rastvoreno dvorište ukazuju kako vojna arhitektura ovdje poprima reprezentativno obličje te pozamašne dimenzije, i u tom će aspektu ostati nedostižan uzor za građanske kuće. Prostorna shema glavnog krila ima, međutim, dvostruki niz prostorija (appartement semi-double) što se čini kao prototipsko rješenje za reduciranu shemu grupiranja $2 \times 2$ prostorije sa svake strane veže, prisutne u zgradi Magistrata i Glavne straže te, kao što ćemo vidjeti, nekolicini kuća. Ključna je razlika, izuzev mjerila i reprezentativnosti, također i smještaj glavne dvorane kata u središnju os iznad ulaza, čime se ujedno ovo zdanje može arhitektonski definirati kao palača.

Valja naglasiti da su javne i vojne zgrade redovito služile i za stanovanje činovnika i časnika za čiji su rad bile namijenjene, pa je unutrašnjost bila uređena adekvatno njihovom položaju i funkciji. ${ }^{16}$ Dužnosnici na višim položajima u takvim su zgradama imali stanove s nekoliko prostorija, a oni nižeg ranga ponekad samo jednu prostoriju. Funkcionalna podjela na stanove nije morala biti vidljiva u tlocrtu, formiranjem grupa prostorija, nego je stan moglo činiti nekoliko prostorija u nizu, privremeno ili trajno uređenih za stanovanje.

\section{Prostorno-oblikovne značajke kuća}

Izduženi oblik parcele donekle je uvjetovao prostornu organizaciju kuća, na način da je krilo prema ulici bilo kraće od
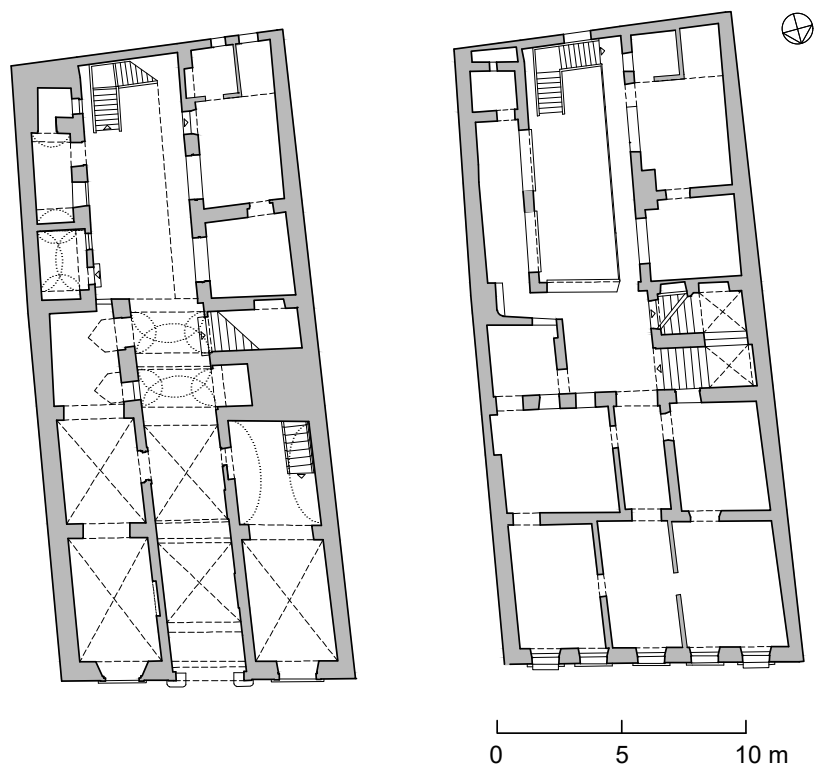

3. Kuća Čerkić (Kuhačeva 19), tlocrt prizemlja i kata (Planoteka IPU) Čerkić House (Kuhačeva 19), ground floor and first floor plans

dvorišnih krila koja su se pružala prema kraju parcele, a u kojima su prostorije bile poredane u nizu. Prizemlje glavnog krila redovito određuje veža koja može biti centrirana u središnju os ili pak decentrirana u jednu od krajnjih. Iako će oba tipa biti prisutna čitavo 18. stoljeće, okrupnjavanje parcela tijekom vremena omogućit će razvoj širih i reprezentativnijih kuća. Prizemlja su uobičajeno bila u funkciji trgovine, gdje su, bočno uz vežu, bili veći svođeni prostori, najčešće s križnim i bačvastim svodovima, a kasnije u 18. stoljeću i češkim kapama. Prvi je kat bio namijenjen stanovanju, a nadstropljene su prostorije bile formirane u grupu ili niz, često dvostruk kao kod vojnih zgrada. U ranije vrijeme kuće

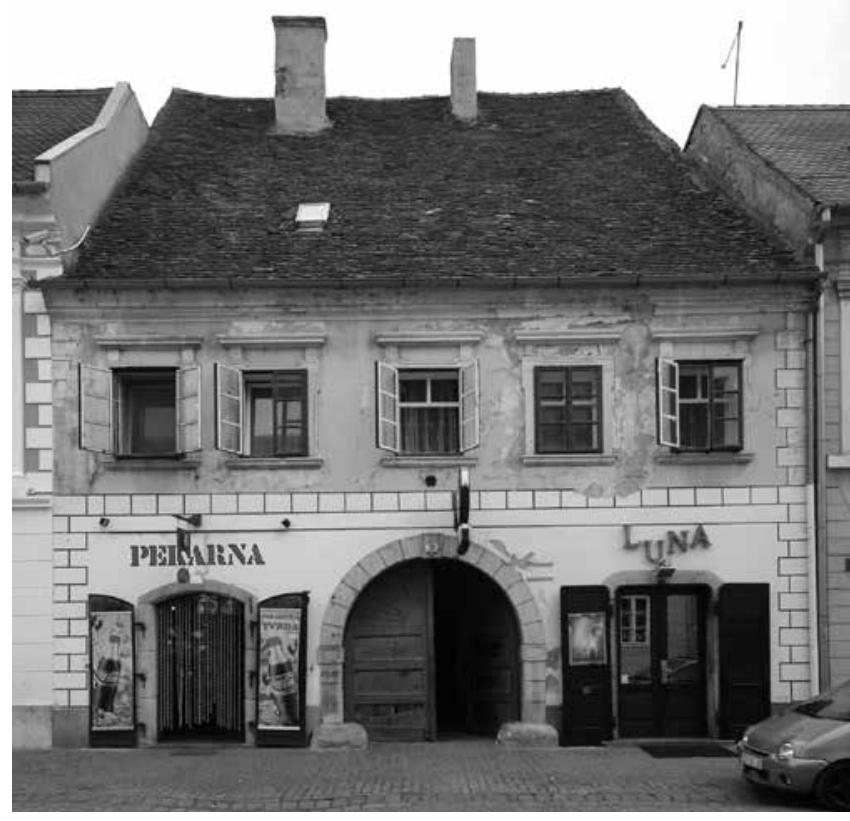

4. Kuća Čerkić (Kuhačeva 19), pročelje (foto: Jovan Kliska, 2012.) Čerkić House (Kuhačeva 19), front façade 

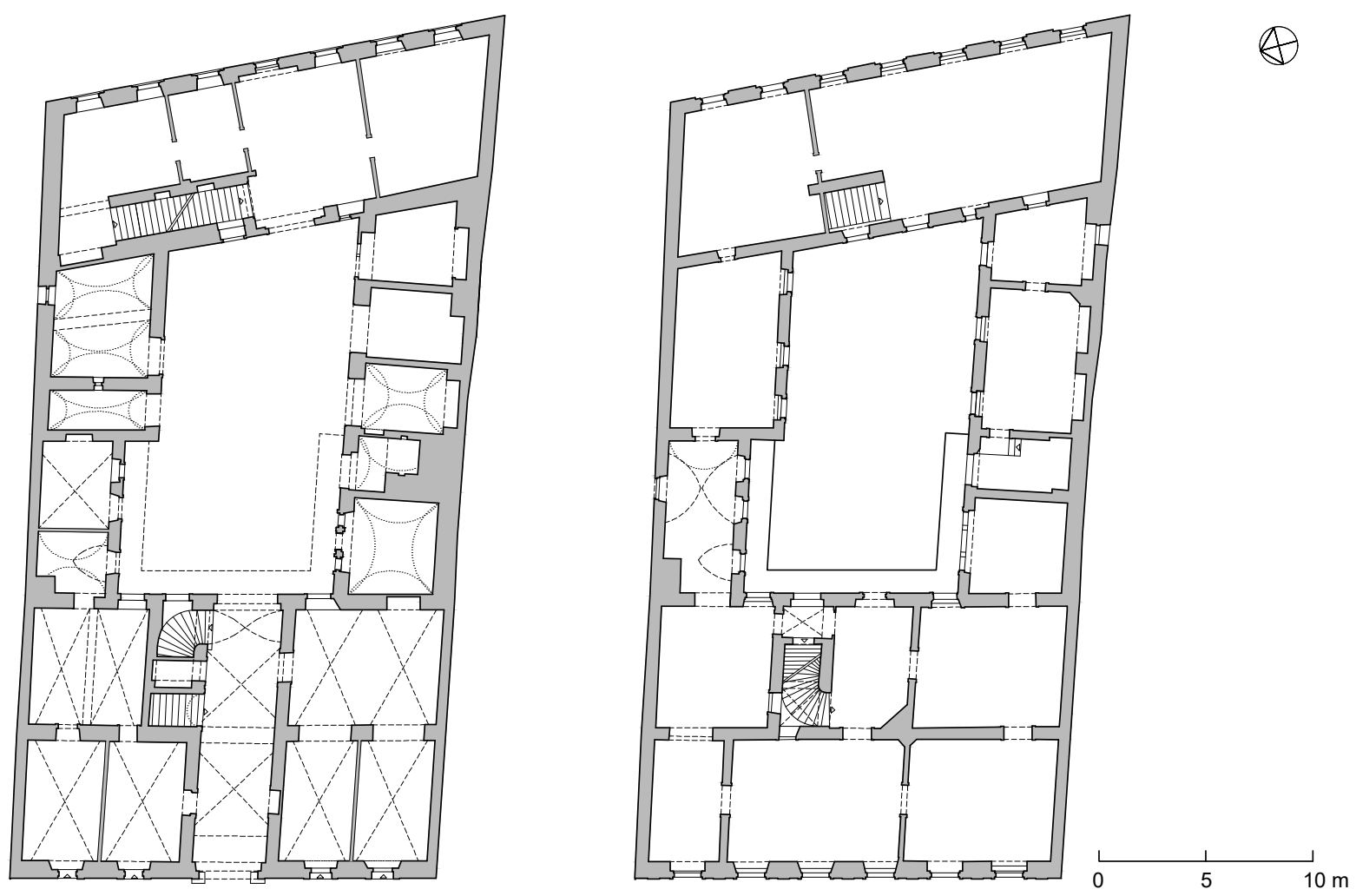

5. Kuća Nikolantin (Trg sv. Trojstva 5), tlocrt prizemlja i kata (Planoteka IPU)

Nikolantin House (Trg sv. Trojstva 5), ground floor and first floor plans

su imale mala i tijesna stubišta, uglavnom drvena, koja su mogla biti smještena unutar perimetra kuće, prislonjena uza začelje ili pak unutar arkadnog hodnika. Tijekom 18. stoljeća stubišta postupno postaju funkcionalnija, povećava im se širina te otvara pristup iz veže, što omogućuje izravan uspon u stambeni prostor. Viši standard bio je ostvaren dimenzijama prostora, posebice širinom veže i stubišta, te stambenih prostorija kata koje su mogle biti bogato opremljene i oslikane, a u tom je smislu važnu ulogu imalo i pročelje.

Relativno rani sačuvani primjer je kuća Čerkić (Kuhačeva 19), ${ }^{17}$ građanska katnica sa simetričnom prostornom organizacijom (sl. 3). Čini ju centrirana, križno svođena veža, u koju se ulazi kroz široki, polukružno zaključeni, kameni portal (sl. 4), a bočno od nje nižu se svođene prostorije prema dubini parcele. Taj inače uobičajen tip prostornog rješenja javlja se u srednjem vijeku, a u nas osobito prevladava u 17. stoljeću. Kod takvog tipa organizacija prostora u katu obično slijedi shemu prizemlja, gdje os veže zaprema središnji hodnik, ali kod kuće Čerkić to nije slučaj, nego se prostorije formiraju $\mathrm{u}$ dva reda, među kojima je jedna manja prolazno predvorje, a tri veće stambene prostorije okrenute su prema ulici. Iako će se taj tlocrtni tip zadržati tijekom 18. stoljeća, zbog uskih parcela mjestimično neće biti moguće ostvariti dovoljno široku vežu, pa će umjesto nje biti samo uzak ulazni hodnik.

U prvoj trećini 18. stoljeća podižu se dvije najveće građanske katnice u Tvrđi, kuća Nikolantin i kuća Pejačević-Niczky, obje položene uz glavni trg te istaknute širinom i visinom. U objema je široka veža pozicionirana u središnjoj osi, a istaknut je i značaj stubišta kojim se iz veže dolazi u pred- vorje u katu te odande u skupinu većih prostorija. U kući Nikolantin (Trg sv. Trojstva 5$)^{18}$ nalazimo uz vežu skupinu četiriju prostorija u prizemlju, sve svođene križnim svodovima, a u katu grupu prostorija koja bi se mogla čitati i kao kraći dvostruki niz (sl. 5). Po današnjoj debljini zidova i bez konzervatorskih istraživanja teško je reći je li postojao centrirani salon, ali se s obzirom na paran broj prozorskih osi može nazrijeti da je veća prostorija s tri prozora mogla biti neznatno izmaknuta izvan osi. Čini se da je kuća prvo bila dvokrilna, sudeći prema planu grada iz 1733 . godine, a nakon toga je dodano i južno bočno krilo, dok su tek u 19. stoljeću i kasnije formirana ostala krila i dvorišne zgrade.

Kuća Pejačević-Niczky (Markovićeva 1$)^{19} \mathrm{u}$ tlocrtu ima približno kvadratni format (sl. 6, 7). Izvorno je bila jednokrilna, tek s nešto istaknutijim volumenom prema jugozapadu, za jednu prostoriju, čineći svojevrstan L-tlocrt. Puni kvadrat formiran je u 19. stoljeću izgradnjom zidanoga ganjka i još jednog stubišta na prostoru malog dvorišta. Nekad centrirana veža kuće dokinuta je naknadnim rušenjem zida prema zapadnoj prostoriji, radi uređenja većeg dućana u prizemlju, pa je ulaz u stambeni dio uspostavljen iz bočne ulice kroz uzak hodnik. Zavojito stubište vodi na kat u središnje predvorje, a veće prostorije nanizane su duž uličnih pročelja. S kućom Nikolantin, čije su strukture nešto bolje sačuvane, ova kuća dijeli, osim sličnosti u tlocrtnim osobinama, također i vrlo blisko oblikovanje pročelja, s rustikom u prizemlju i toskanskim pilastrima u katu, o čemu će još biti riječi.

Sličnog rješenja kuća je vojnog ljekarnika (sl. 8) na glavnom trgu u Tvrđi (Kuhačeva 15), koju možemo zvati i kuća Eu- 

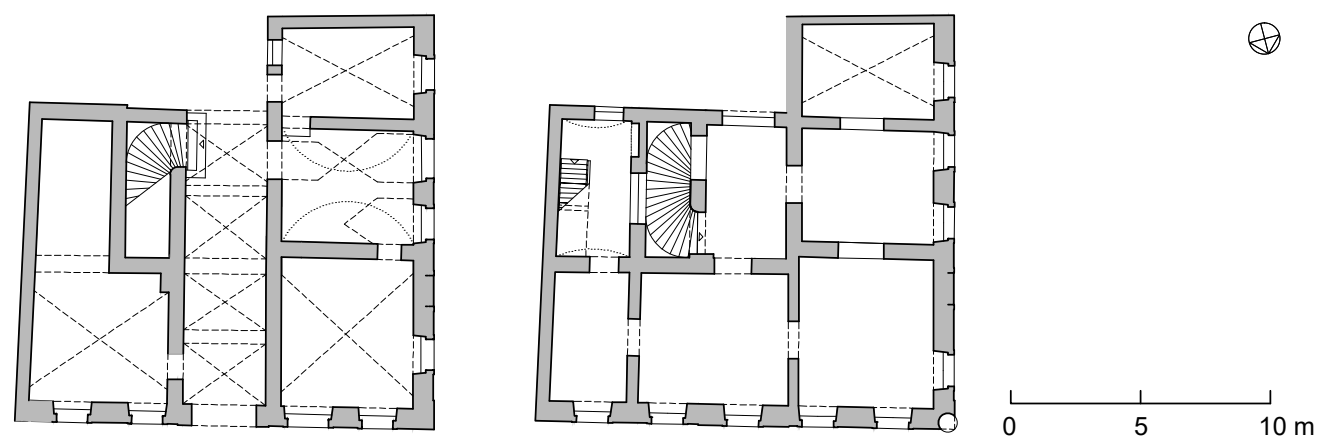

6. Kuća Pejačević-Niczky (Markovićeva 1), tlocrt prizemlja i kata, rekonstrukcija izvornog stanja (Planoteka IPU)

Pejačević-Niczky House (Markovićeva 1), ground floor and first floor plans, reconstruction of original state

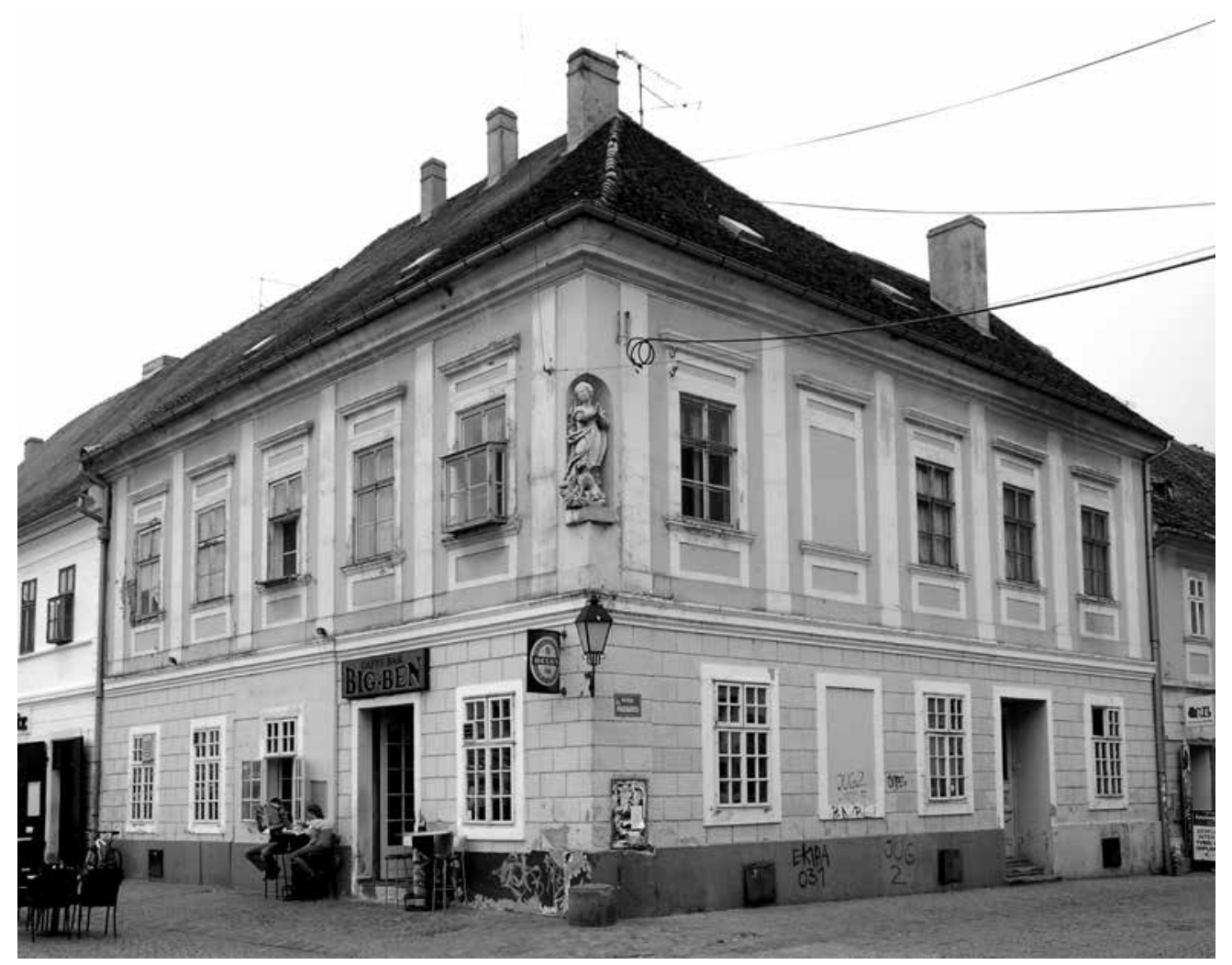

7. Kuća Pejačević-Niczky (Markovićeva 1), pročelja (IPU)

Pejačević-Niczky House (Markovićeva 1), front façade

lenscheng-Natorp, prema vlasnicima koji su je posjedovali sredinom 18. stoljeća. ${ }^{20}$ Unatoč popriličnoj širini parcele, koja je moguće bila razlog trokrilnog rješenja, rezultat je u izvedbi bio nešto skromniji, $s$ niskom visinom etaža i manjim prozorima na glavnom pročelju. Središnje smještena veža u prizemlju je križno svođena, te naknadno produljena prema jugu za jedan travej s češkom kapom. Sa zapadne strane veže su dvije prostorije razdvojene lučnim prolazima, a s istočne jedna velika prostorija s četiri traveja križnog svoda poduprtima na središnji stup. Na katu je manja grupa nadstropljenih prostorija, organizirana u dva niza, kao kod kuće Nikolantin, s tim da je širi hodnički prostor dodan tek u 19. stoljeću, zajedno sa stubištem i lateralnim krilima.
Identična organizacija ponovila se na iduće dvije kuće prema istoku. Na kući Bittner (Kuhačeva 13, sl. 9), podignutoj 1785./1786. godine ${ }^{21}$ i radikalno obnovljenoj u 19. stoljeću, dvije su prostorije sa svake strane centrirane veže, sve križno svođene, a u prizemlju se čita naknadna nadogradnja dvorišnih krila u kojem prevladavaju svodovi u obliku čeških kapa, karakteristični za drugu polovinu 18. stoljeća. Uglovna kuća Kalleneck (Kuhačeva 11) sagrađena je na samom početku 18. stoljeća, kada je vjerojatno bila prizemnica s uzdignutim potkrovljem i zabatom u središnjoj osi, ali je u drugoj četvrtini stoljeća i kasnije višekratno dograđena za stan tvrđavskog pukovnika. ${ }^{22}$ Usporedba današnjeg stanja s nacrtom iz 1850. (sl. $10)^{23}$ pokazuje da je u prizemlju očuvana povijesna situacija, 

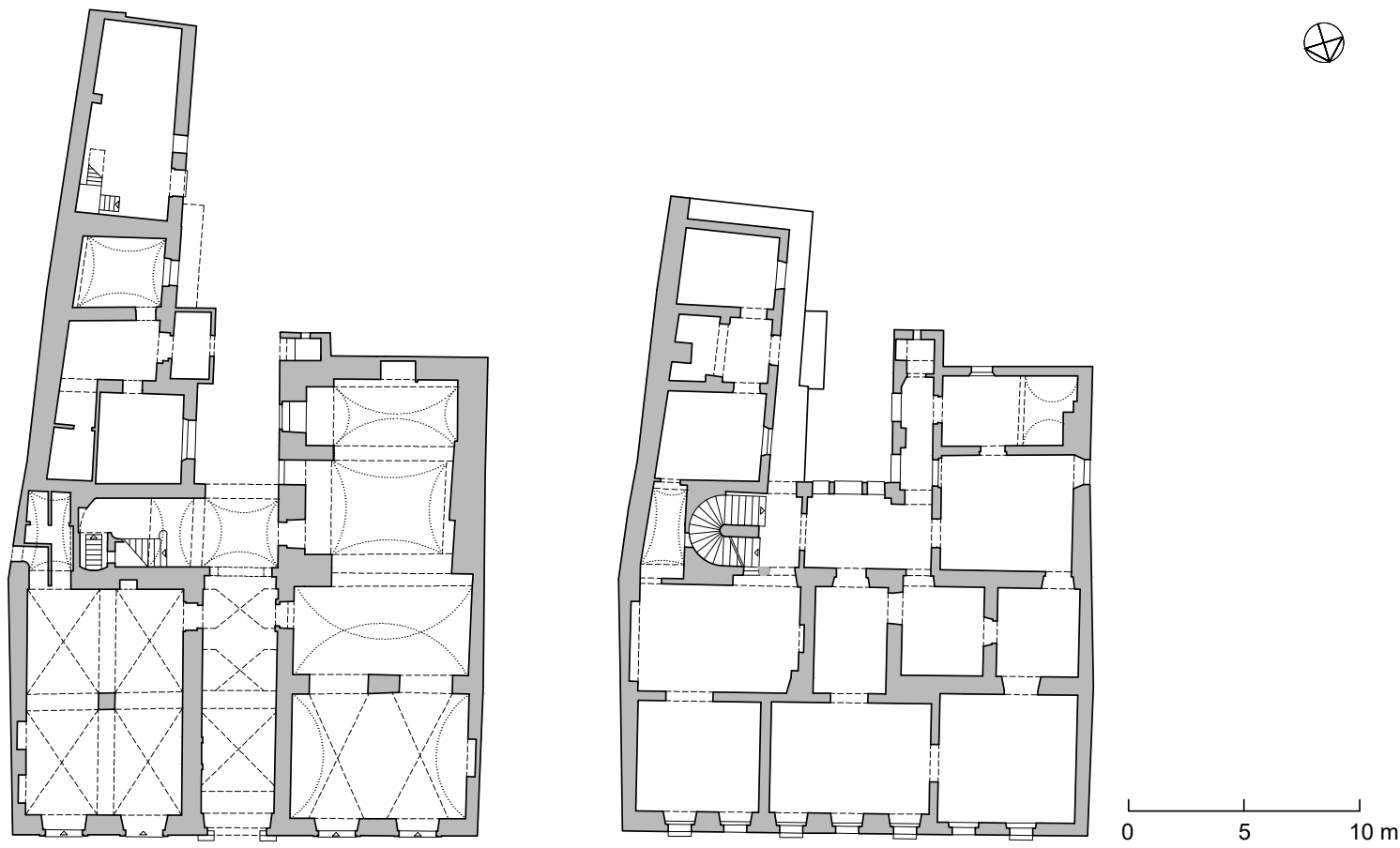

8. Kuća Eulenscheng-Natorp (Kuhačeva 15), tlocrt prizemlja i kata (Planoteka IPU)

Eulenscheng-Natorp House (Kuhačeva 15), ground floor and first floor plans
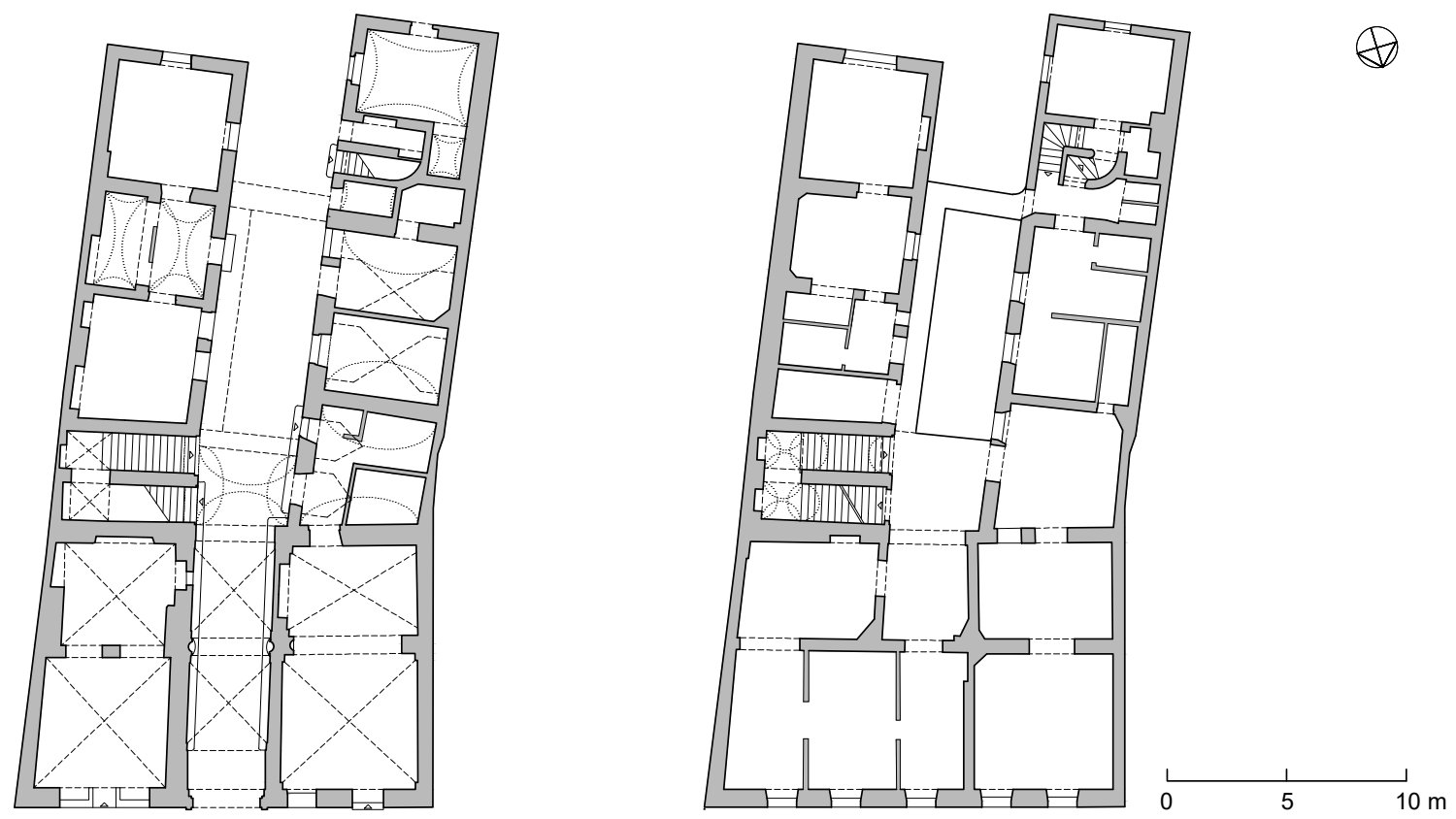

9. Kuća Bittner, (Kuhačeva 13), tlocrt prizemlja i kata (Planoteka IPU)

Bittner House (Kuhačeva 13), ground floor and first floor plans

u glavnom krilu s centriranom vežom i po dvije prostorije sa svake strane, a na katu je pregradnjama dokinut centralno položen salon koji se pružao u osi veže te zajedno s drugim prostorijama imao izlaz na dvorišni hodnik.

U dvjema najvećim građanskim kućama u Tvrđi usvojena prostorna shema poprimit će veće dimenzije, s produljenjem krila i dugačkim nizovima prostorija, a artikulacijom će se približiti tipologiji palače. Kuća Kostić (Kuhačeva 23) može se datirati u 1740 -e godine, ${ }^{24}$ a njezin izvorni izgled poznat je s nacrta iz 1774. (sl. 11), ${ }^{25}$ nastalog prilikom kupnje kuće za generalov stan. ${ }^{26}$ Trokrilna građevina položena je glavnim krilom uz ulicu, a bočnim dvama prema zapadu, pri čemu su u obje etaže prostorije nanizane uz arkadni hodnik prema dvorištu. U glavnom je krilu u prizemlju široka veža u 


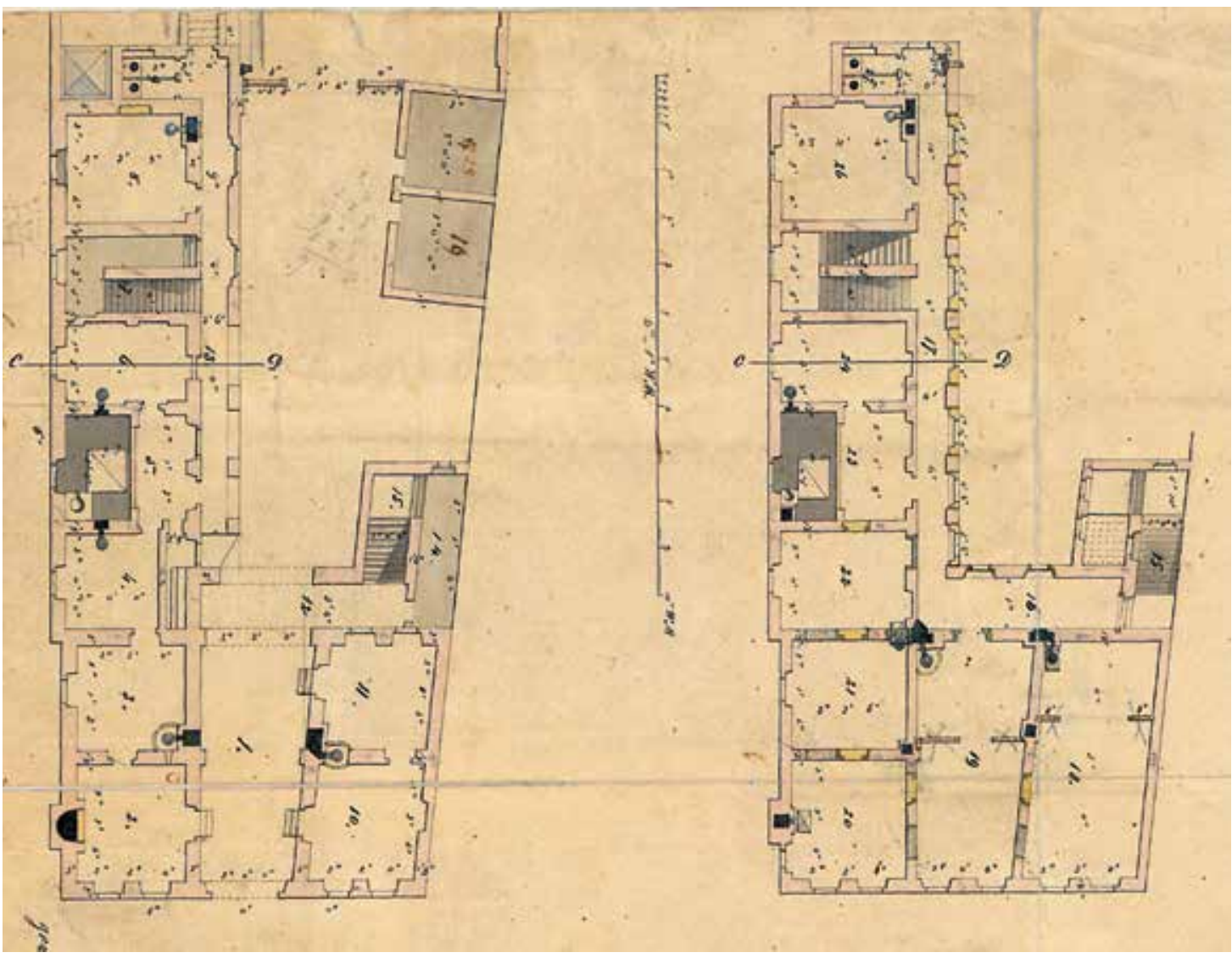

10. Kuća Kalleneck - stan pukovnika (Kuhačeva 11), projekt pregradnje iz 1850., tlocrt prizemlja i kata sa žuto označenim planiranim zahvatima (NSK)

Kalleneck House - Colonel's apartment (Kuhačeva 11), remodelling project from 1850, ground floor and first floor plans with the planned interventions indicated in yellow

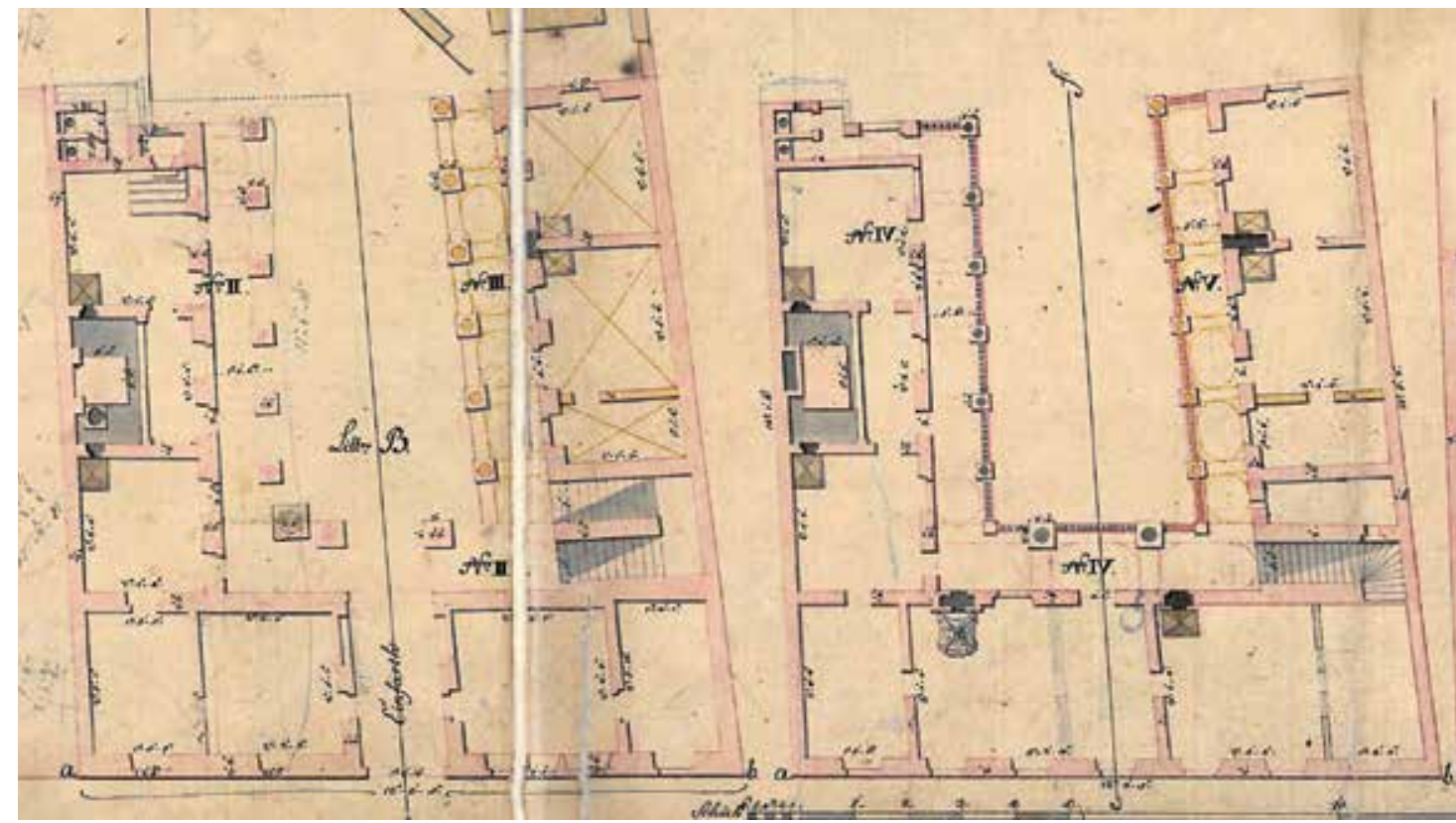

11. Kuća Kostić (Kuhačeva 23), projekt pregradnje za generalov stan, tlocrt prizemlja i kata sa žuto označenim planiranim zahvatima, G. Tomerlin, 1773. (NSK)

Kostić House (Kuhačeva 23), remodelling project for the general's apartment, ground floor and first floor plans with the planned interventions indicated in yellow, G. Tomerlin, 1773 


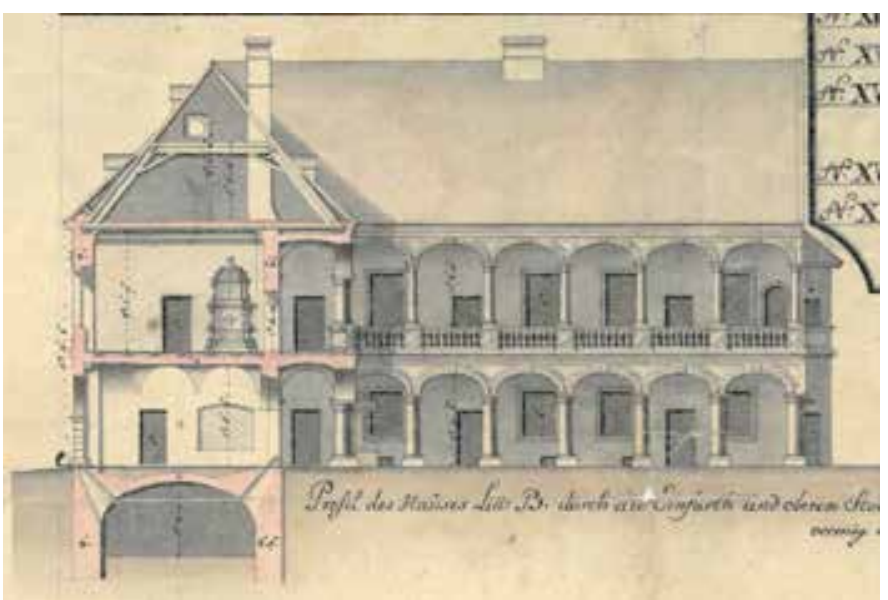

12. Kuća Kostić (Kuhačeva 23), projekt pregradnje za generalov stan, presjek i dvorišno pročelje istočnog krila, G. Tomerlin, 1773. (NSK) Kostić House (Kuhačeva 23), remodelling project for the general's apartment, cross-section and courtyard façade of the east wing, $G$. Tomerlin, 1773

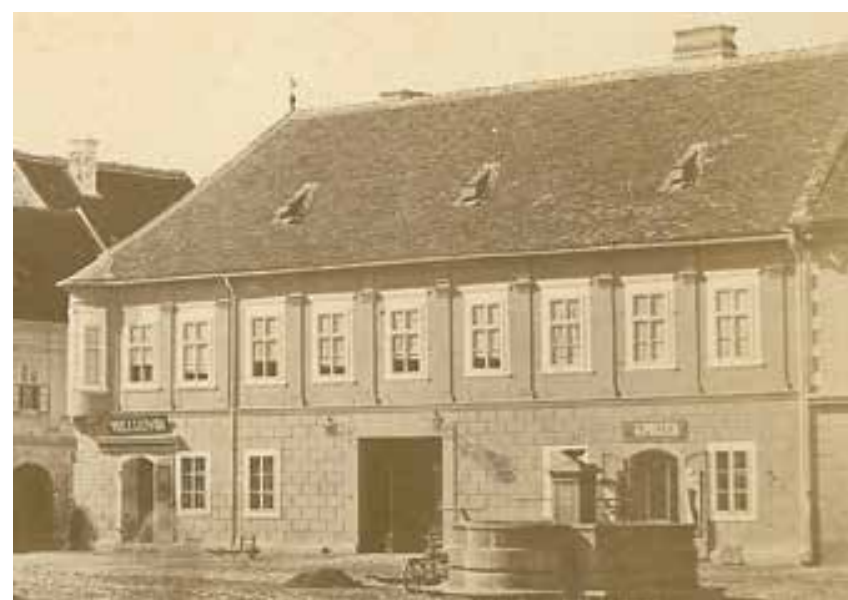

13. Kuća Ritter (Trg sv. Trojstva 1), pročelje, detalj fotografije J. Exnera, 1877. (MSO)

Ritter House (Trg sv. Trojstva 1), front façade, detail of a photograph by J. Exner, 1877

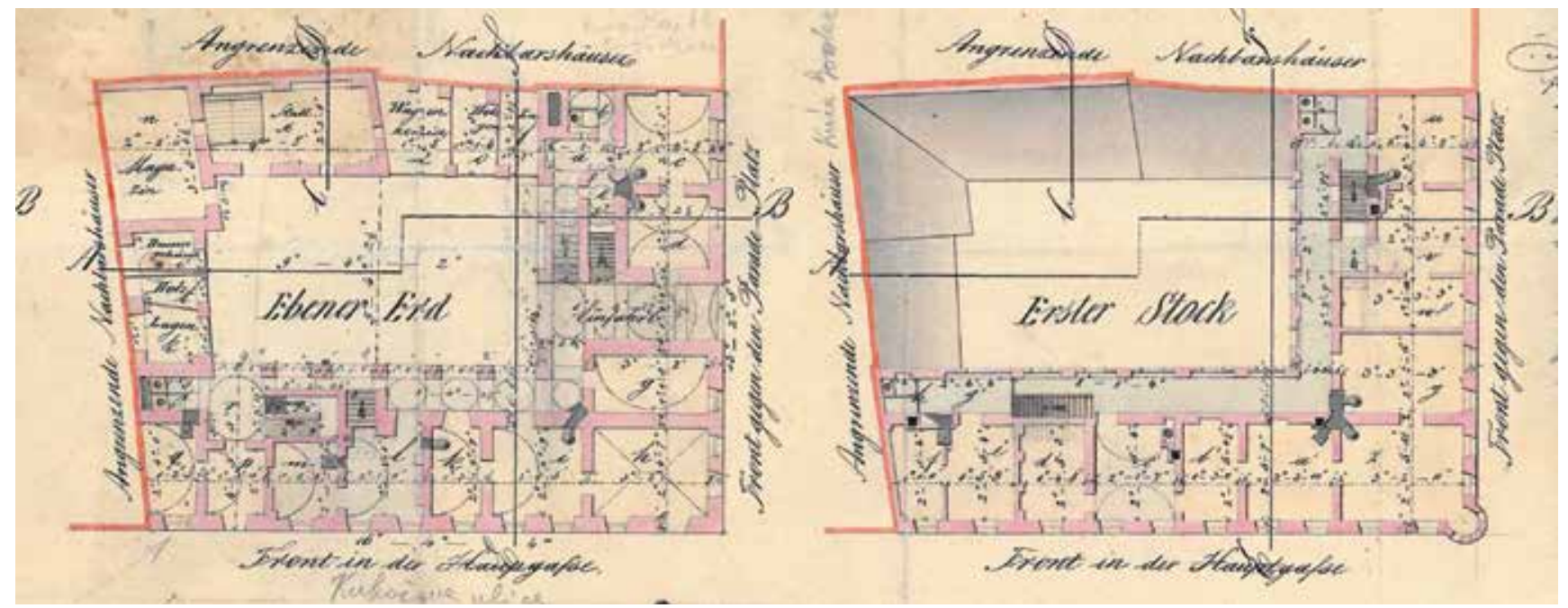

14. Kuća Ritter (Trg sv. Trojstva 1), tlocrt prizemlja i kata, autor: Franz Fux, 1853. (NSK)

Ritter House (Trg sv. Trojstva 1), ground floor and first floor plans, author: Franz Fux, 1853

središnjoj osi, koja povezuje ulicu i dvorište, a nudi i uspon drvenim stubištem na kat. Bočno od veže je s obje strane po jedna dućanska prostorija koja je nekad imala uz ulicu vrata "na koljeno". Na katu su se prema ulici nalazile dvije velike prostorije sa po tri prozora, od kojih se središnja raspoznaje po dekorativno oblikovanoj kaljevoj peći kao salon te jedna manja soba s jednim prozorom. Arkadni hodnik uz dvorišna pročelja izvorno se nastavljao kroz dva krila, sjeverno (glavno) $\mathrm{i}$ istočno, a nacrt iz 1773. predstavlja projekt kojim se planiralo izvesti arkade i uza zapadno krilo. Arkade danas više ne postoje, no nacrt pokazuje da su bile sazidane kamenim stupovima i balustradama (sl. 12). Svaku sumnju da su arkade doista postojale otklanjaju i projekti njihova zazidavanja, datirani u 1839. godinu. ${ }^{27} \mathrm{U}$ glavnom krilu nalazile su se veće arkade masivnih toskanskih stupova, a u bočnima niz od šest elegantnih lukova u prizemlju i isto toliko na katu, gdje su vitki toskanski stupovi podignuti na postamente, a između njih ritmizirane balustrade. Uporaba velike količine kamena u sredini poput osječke, gdje se uobičajeno gradilo opekom, ukazuje na to da je gradnja kuće bila izuzetno skup pothvat imućnog investitora, a uzimajući u obzir visoku oblikovnu i estetsku vrijednost ovoga nesvakidašnje bogatog rješenja, primjerenog stambenim palačama većih gradova, zaista je velika šteta što danas nije više sačuvano.

Drugi primjer izduljena je katnica na zapadnoj strani glavnog trga, kuća Ritter (Trg sv. Trojstva 1), koja zaprema južni dio današnje zgrade Glazbene škole, a izvorno stanje vidljivo je na povijesnim fotografijama (sl. 13). ${ }^{28}$ Podigao ju je Georg Ritter, protokirurg Virovitičke županije, kupivši dvije susjedne kuće 1768. godine ${ }^{29}$ te ih spojio i dogradio uspostavivši još jedno zdanje s odlikama palače. Nacrt iz 1853. godine (sl. 14) ${ }^{30}$ pokazuje njezin unutrašnji raspored. Riječ je o uglovnici u kojoj su tlocrti obje etaže bili koncipi- 

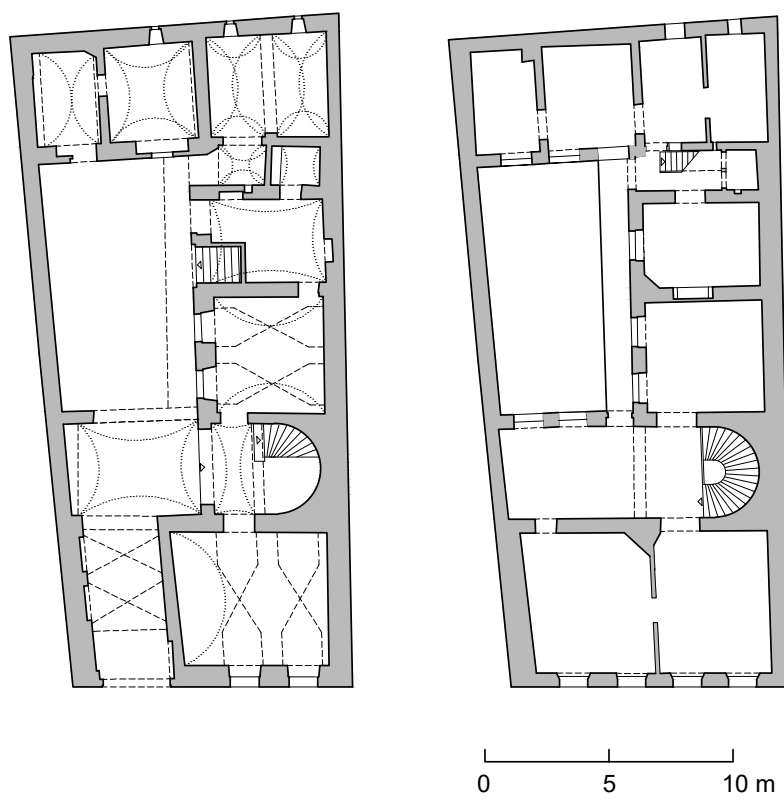

15. Kuća Gegić (Kuhačeva 21), tlocrt prizemlja i kata (Planoteka IPU) Gegić House (Kuhačeva 21), ground floor and first floor plans

rani nizanjem prostorija uz dvorišni hodnik, doduše ovdje s masivnim zidanim arkadama. U središnjoj osi prizemlja, prema trgu, nalazila se nadsvođena veža, a na katu veliki salon na samom spoju dvaju krila. Taj je ugao na pročelju bio istaknut kružnim erkerom, još jednim karakterističnim elementom 18. stoljeća, koji je i danas sačuvan, ali je u 19. stoljeću preoblikovan, kao i čitavo pročelje.

Spomenimo još i dvije manje, ali značajne kuće kod kojih se javlja decentrirani položaj veže, čime se očito željelo prilagoditi uskoj parceli. Veža se u ovom slučaju smješta bočno uz perimetralni zid, a uz nju su različito dimenzionirane grupe prostorija. Primjeri za to su kuća Gegić (Kuhačeva 21, sl. 15, 16) i kuća Gegić-Sturm (Kuhačeva 25, sl. 17), ${ }^{31}$ obje dvokrilne, s bočno položenom vežom te jednom ili dvije prostorije uz ulično pročelje i nekoliko duž dvorišnog krila. $\mathrm{Na}$ katu glavnog krila su po tri prostorije čiji raspored ne odgovara onima u prizemlju. Takvo je odstupanje, između ostalog, bilo predodređeno i položajem krakova stubišta.

Iz navedene se analize mogu razabrati tri tipa prostorne organizacije. Prvi tip (1) ima centriranu vežu i tendenciju simetričnoga grupiranja prostorija s obje njezine strane, bilo da je riječ o četiri, dvije ili pak samo jednoj prostoriji, koja je mogla biti podijeljena na dva ili više svodnih traveja. Ako se javljaju bočna krila, u njima se prostorije redaju u nizu. Kod drugog tipa (2) veža je također centrirana, ali se prostorije ne grupiraju, nego nižu uz dvorišne hodnike, kako u glavnom, tako i bočnim krilima. Treći tip (3) je asimetrične organizacije, s decentriranom vežom i prostorijama samo $s$ jedne njezine strane. Organizacija kata, nevezano za prizemlje, može biti riješena nekolicinom prostorija u nizu ili pak skupinom formiranom u dva kraća niza, što je najčešći slučaj. Ti koncepti u projektiranju stambenih kuća nisu bili

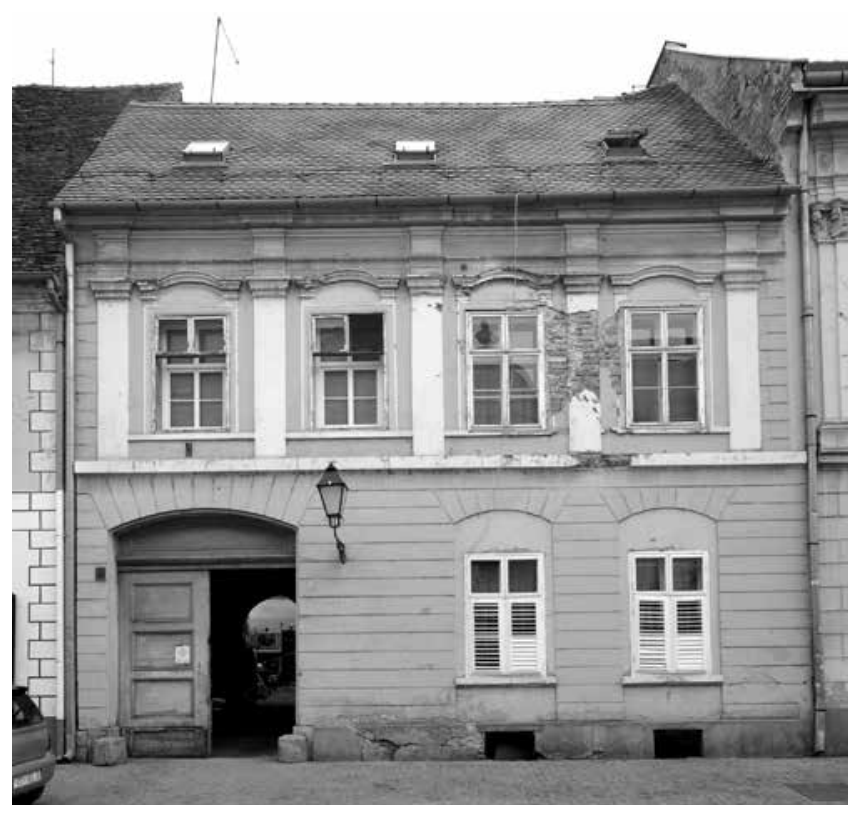

16. Kuća Gegić (Kuhačeva 21), pročelje (foto: Jovan Kliska, 2012.) Gegić House (Kuhačeva 21), front façade

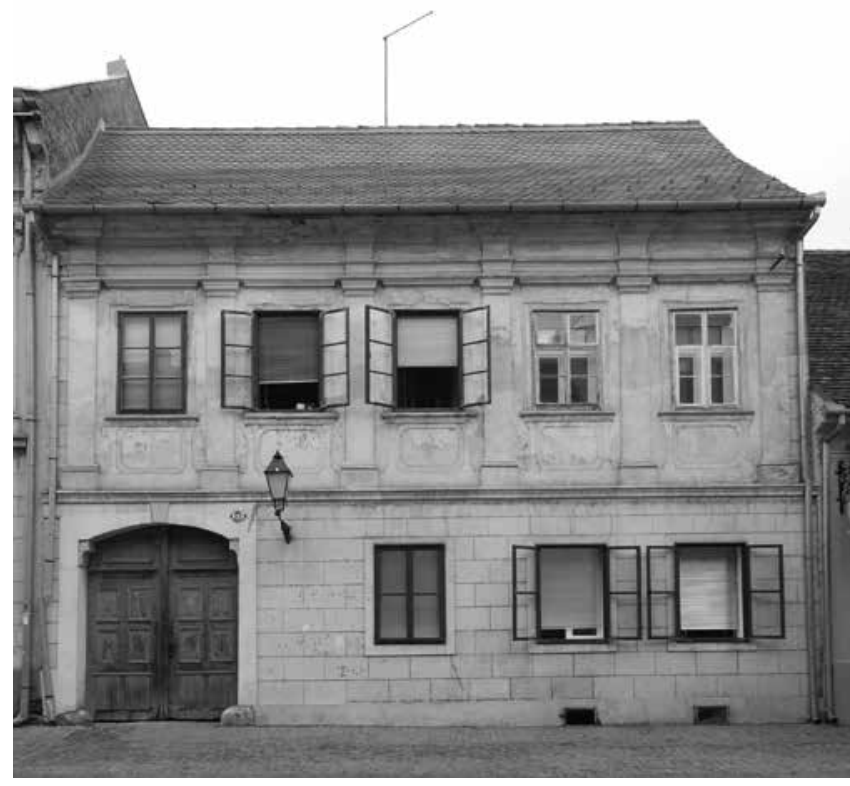

17. Kuća Gegić-Sturm (Kuhačeva 25), pročelje (foto: Jovan Kliska, 2012.)

Gegić-Sturm House (Kuhačeva 25), front façade

originalna, autorska rješenja, nego uobičajeni modeli stambene izgradnje na širem prostoru.

\section{Elementi oblikovanja pročelja}

Građanske kuće u Tvrđi odlikovale su se i bogato artikuliranim pročeljima, a pročelja spomenutih odražavala su reprezentativnim oblikovanjem i viši standard stanovanja. U mnogima nalazimo brojne zajedničke elemente. Prizemlja 


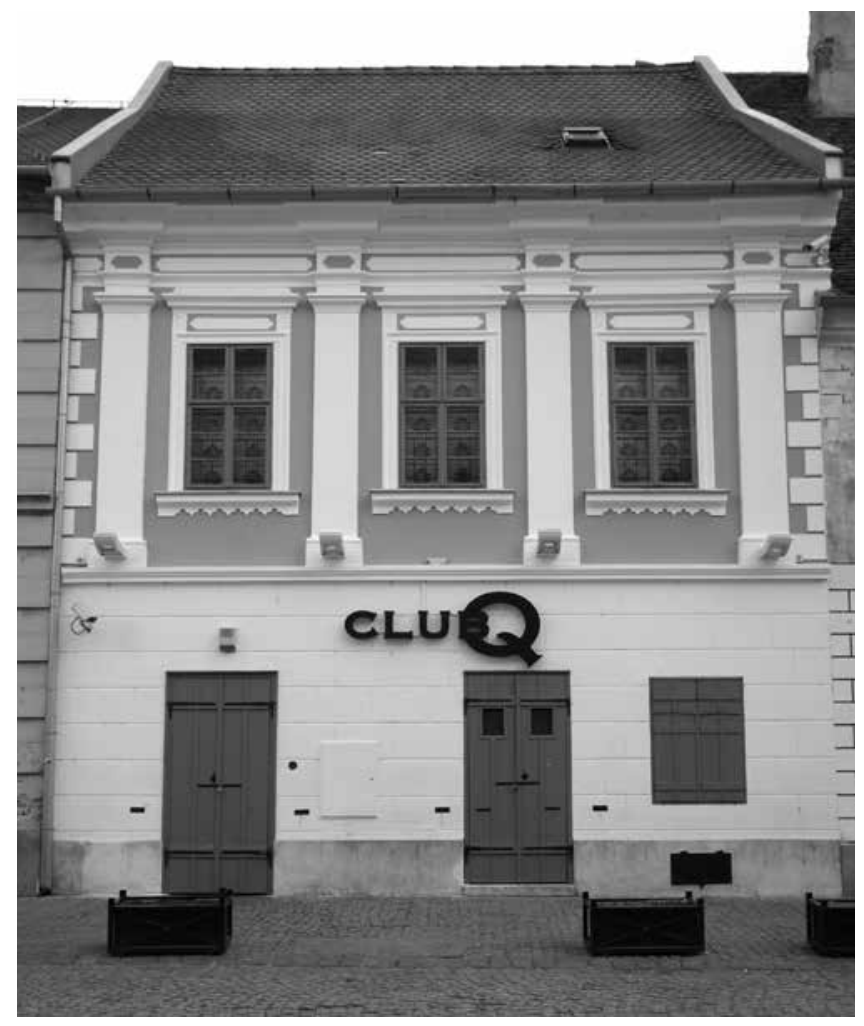

18. Kuća Martinović (Kuhačeva 17), pročelje (foto: Jovan Kliska, 2012.)

Martinović House (Kuhačeva 17), front façade su uobičajeno obrađena stiliziranom rustikom u žbuci, a od otvora se ističu kameni portal, ulazi u dućane, često "na koljeno" te manji prozori. Na katu prevladavaju veliki prozori i žbukana dekoracija koju čine razdjelni i završni vijenac, prozorski okviri s klupčicama i nadstrešnicama, ugaoni kvadri, a na nekolicini i niz toskanskih pilastara. Takvu raščlambu imaju kuća Gegić (Kuhačeva 21, sl. 16), kuća Gegić-Sturm (Kuhačeva 25, sl. 17), kuća Martinović (Kuhačeva 17, sl. 18), kuća Nikolantin (Trg sv. Trojstva 5, sl. 19), a imale su i kuća Pejačević-Niczky (Markovićeva 1) te kuća Ritter (Trg sv. Trojstva 1). Štoviše, pilastri, njihove baze i kapiteli te vijenci, kao i druga dekoracija, izrazito sliče jedni drugima. ${ }^{32} \mathrm{U}$ detalju su najsličnije kuća Nikolantin i kuća Pejačević-Niczky, a ostale ponešto variraju oblicima profilacija, bazama i kapitelima pilastara, ravnim ili zaobljenim prozorskim nadstrešnicama i drugim elementima. Znatno bogatiju artikulaciju trostrukim pilastrima ima i najveća među njima, kuća Kostić (Kuhačeva 23, sl. 20), gdje su kapiteli, kao i spomenuta arkatura na začeljima bili izrađeni od kamena. Dodatni je efekt postignut dekorativnom obradom lišća na kapitelima, pa pilastri iznimno nisu toskanskoga, nego kompozitnog reda (sl. 21).

Snopovi s tri pilastra od kojih je jedan u sredini te zaklanja dva bočna polovinom njihove širine, karakterističan je dekorativni motiv s vojnih zgrada. ${ }^{33} \mathrm{Na}$ palači Generalkomande upravo takvi trostruki snopovi razdjeljuju prozorske osi u zoni prvoga i drugog kata, te čine glavni element raščlambe. Na zgradi Glavne straže široki, zdepasti, trostruki snopovi

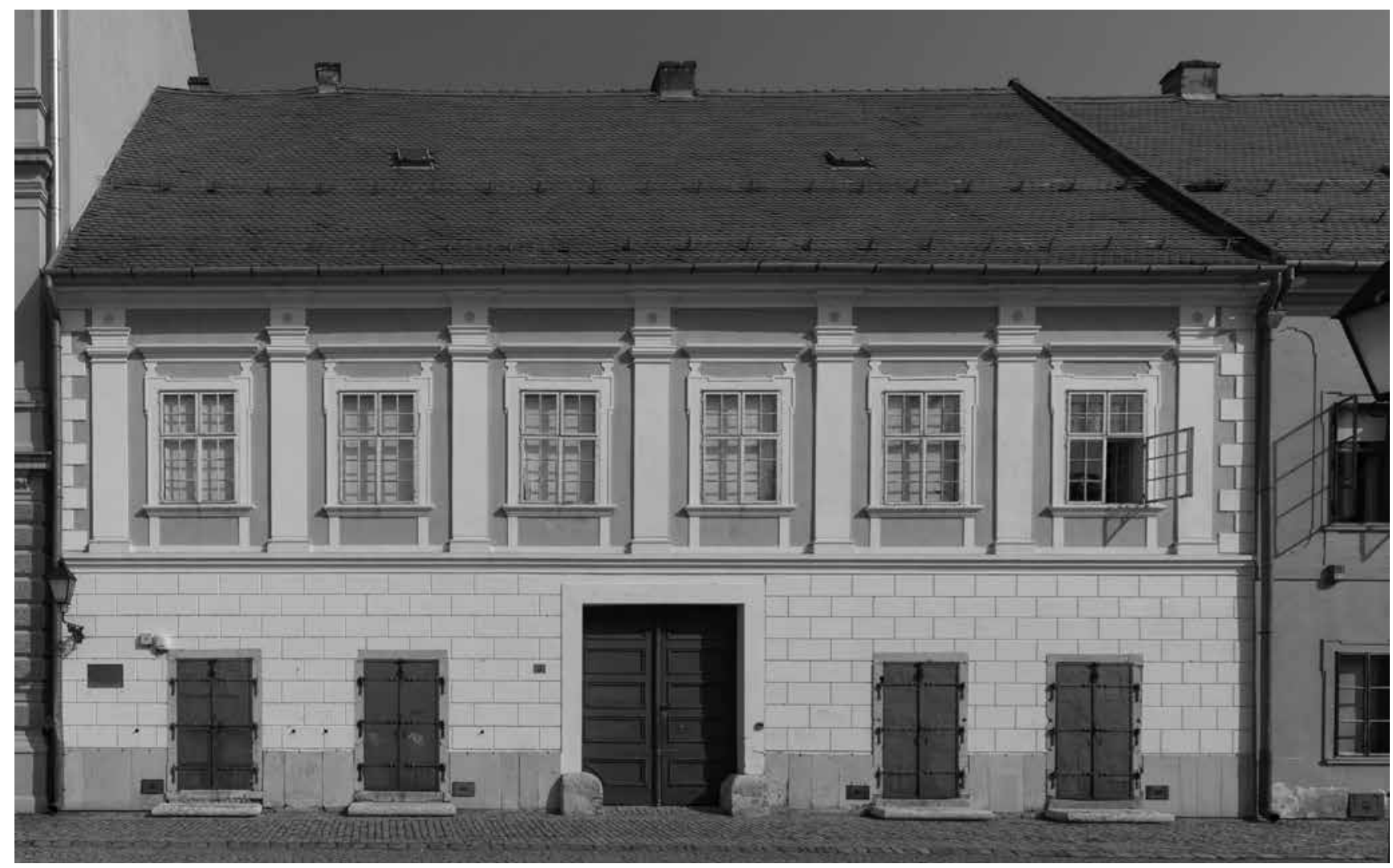

19. Kuća Nikolantin (Trg sv. Trojstva 5), pročelje (foto: Jovan Kliska, 2012.)

Nikolantin House (Trg sv. Trojstva 5), front façade 


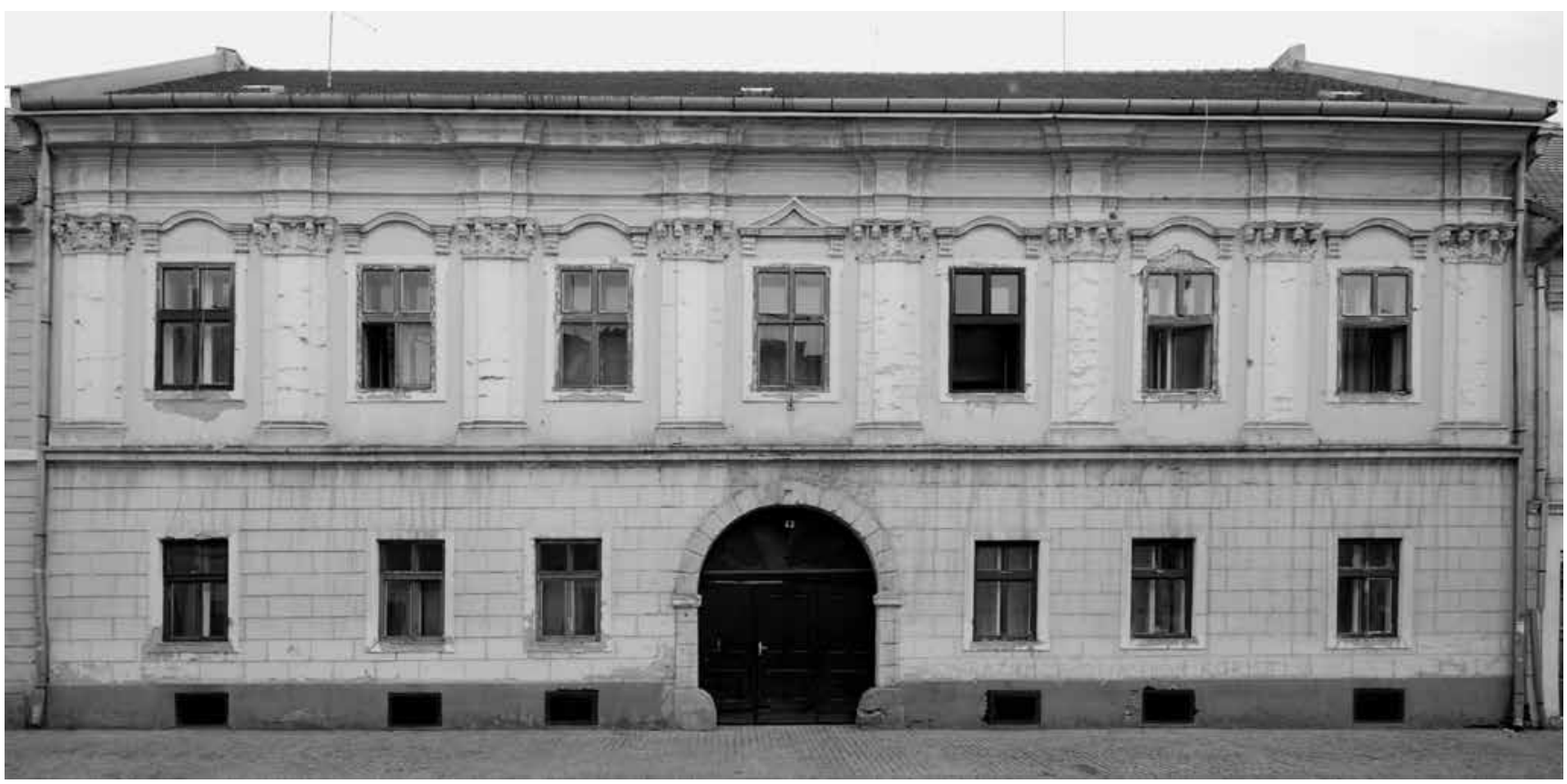

20. Kuća Kostić (Kuhačeva 23), pročelje (foto: Jovan Kliska, 2012.) Kostić House (Kuhačeva 23), front façade

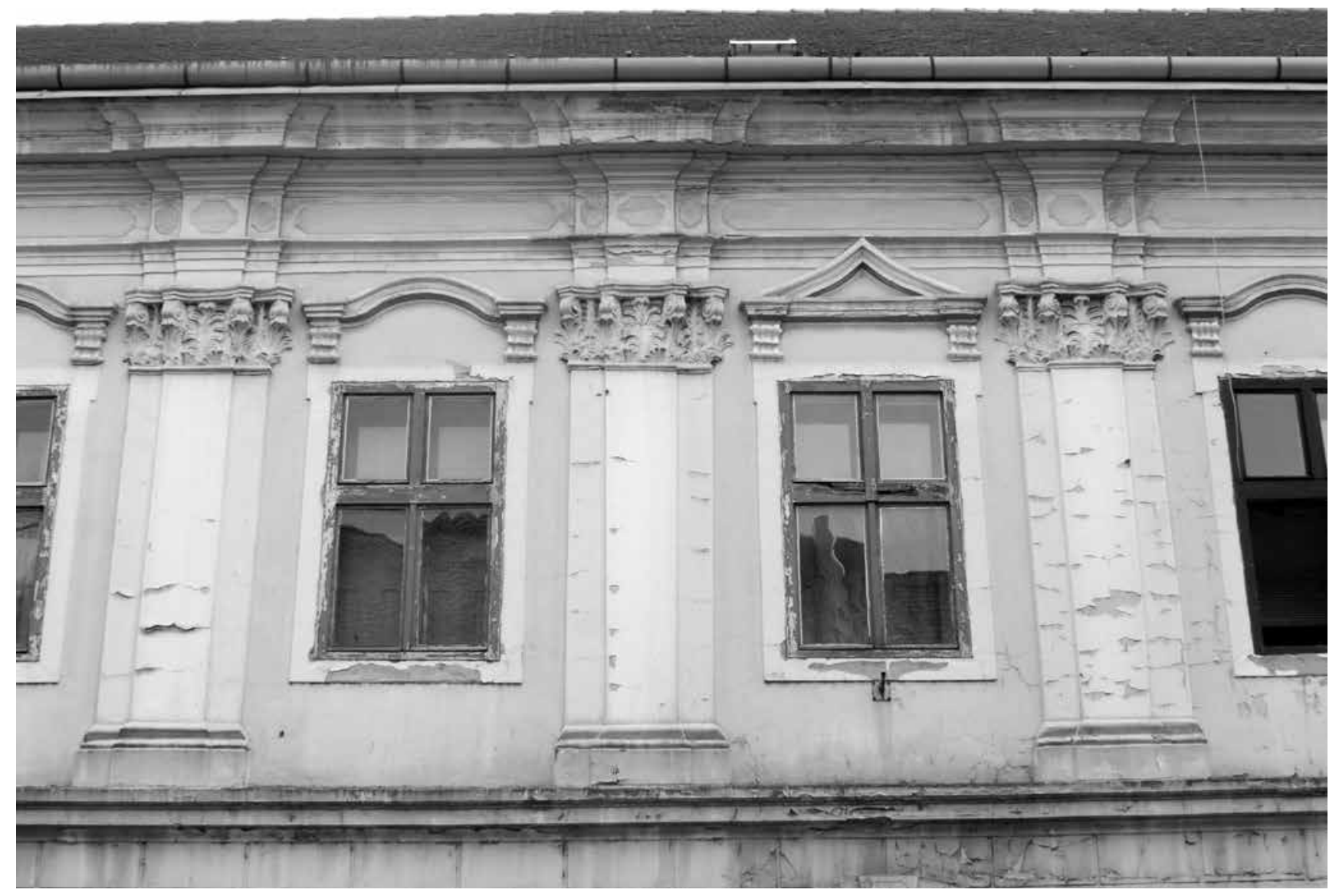

21. Kuća Kostić (Kuhačeva 23), detalj pročelja sa snopovima pilastara (foto: Jovan Kliska, 2012.) Kostić House (Kuhačeva 23), façade detail with pilasters 
omeđuju središnju os pročelja, ali se javljaju i iznad, na plohi tornja, te nastavljaju obratima u zoni vijenca. Na zgradi Velike oružane široki trostruki snopovi omeđuju glavni ulazni portal, podupirući prekinutu trokutastu nadstrešnicu koja ga nadvisuje. Korištenje tog motiva na vojnim zgradama, a zatim i njegova pojednostavljena primjena na kućama, upućuje na vjerojatnost da je riječ o istim projektantima, moguće vojnim inženjerima. ${ }^{34}$ Valja naglasiti da su Generalkomanda i Glavna straža podignute 1720 -ih godina, pa bi najranije kuće s pilastrima morale potjecati iz tog vremena. No s obzirom da se ta dekoracija na kućama javlja sve do kasnih 1760-ih godina, očito je bila riječ o trendu koji se zadržao relativno dugo.

Drugi, snažno prisutan element raščlambe, istaknuti su i uleknuti medaljoni, najčešće pravokutnog oblika sa segmentno zasječenim uglovima, kojima su prekrivene plohe pročelja. Medaljoni su najranije primijenjeni na pročelju zgrade Gradskog magistrata (oko 1702.), gdje su krivuljni oblici uleknutih medaljona bili izvedeni monokromno, $\mathrm{u}$ tamnosivo pigmentiranoj žbuci, baš kao i ostatak pročelja. ${ }^{35}$ Nalazimo ih, u manjoj mjeri, gotovo na svim spomenutim građanskim kućama, i to prvenstveno kao motiv na vijencu ili ispod njega, dok su na nekima dominantan element artikulacije. Primjerice, na kući Streicher (Franjevačka 3) nekada su bili crveni medaljoni na bijeloj osnovi, datirani u fazu između 1758. i 1765. godine, ${ }^{36}$ na pročelju kuće Eulenscheng ružičastocrveni medaljoni, a na kući Kalleneck (Kuhačeva 11) žuti medaljoni na bijeloj osnovi. ${ }^{37}$ Kasnobaroknih zavojitih oblika s dodatnom ornamentacijom, medaljoni su na pročelju vlastite kuće graditelja Johanna Hatzingera iz 1768. godine (Markovićeva 7). ${ }^{38}$ Riječ je o nedavno prepoznatom graditelju koji je djelovao u Osijeku i Vukovaru te bio angažiran na gradnji palače Srijemske županije u Vukovaru (1770. - 1773.), ${ }^{39}$ gdje su primijenjeni upravo spomenuti tipovi medaljona krivuljnih oblika kartuša i rokaja. ${ }^{40}$

U kontekstu kasnobaroknog oblikovanja, a općenito i u korpusu stambene arhitekture Tvrđe, posve je iznimna kuća Kohlhoffer (Franjevačka 5) čije se pročelje datira u 1775. godinu. ${ }^{41}$ Riječ je o kamenoj dekoraciji koju čine volutno povijene, prekinute nadstrešnice s perforiranim školjkama, samostojeći rokaji u obliku uzdignutih vaza i dekorativ- ni lambrekeni na parapetima, sve to u sustavu tektonske kompozicije slijepih arkada i lezena koje uokviruju plohe. Projekt toga bogatog pročelja pripisuje se krugu oko ugarske graditeljske radionice Mayerhoffer, čiji su članovi putem vojnih i komorskih vlasti dolazili u Slavoniju i Osijek. ${ }^{42}$ Sama unutrašnjost kuće, s druge strane, relativno je skromna. U prizemlju izostaje veža, iako je hodnik pozicioniran u središnjoj osi, a na katu se nalazi svega nekoliko prostorija. Pročelje, naime, nastaje kao kulisa ranije građevne strukture, vjerojatno iz 1734. godine.

Tijekom 19. i 20. stoljeća, pročelja većine kuća u Tvrđi, osobito u zoni prizemlja, doživjela su značajne promjene. Adaptacijama dućana nekadašnji su manji prozori i uski portali prošireni i preoblikovani, ili su na njihova mjesta postavljeni drveni izlozi. Kolnim ulazima su promijenjeni formati iz prvotnih lučnih kamenih portala u pravokutne i segmentne otvore (kuće Nikolantin, Pejačević-Niczky, Eulenscheng, Gegić, Ritter), dokinuta su im kamena vrata na koljeno (kuće Nikolantin, Pejačević-Niczky, Kostić), nekad česta na osječkim kućama, a žbukana dekoracija pojednostavljena ili uklonjena (kuća Pejačević-Niczky). ${ }^{43}$ Pojedina su pročelja u cijelosti preoblikovana u duhu historicizma (kuće Bittner, Ritter). ${ }^{44}$

\section{Zaključak}

Gradnjom reprezentativnih građanskih katnica tijekom prve polovine 18. stoljeća usvajaju se prostorno-oblikovni obrasci koji će u Tvrđi, u većoj ili manjoj mjeri, biti prisutni sve do prve polovine 19. stoljeća. Prostorne koncepcije i raščlamba nalikuju onima na većim javnim i vojnim zgradama koje podižu graditelji i inženjeri angažirani na gradnji i održavanju tvrđave, pa se vjerojatno autorstvo projekata većine tih građanskih kuća može pripisati upravo njima. Kuće su uobičajeno prolazile unutrašnje preobrazbe te oblikovnostilske mijene vanjštine koje je moguće spoznati tek detaljnim konzervatorskim i povijesnim istraživanjima svake od njih pojedinačno, a u ovom radu pokušalo se identificirati one najvažnije. 


\section{Bilješke}

1

Ovaj rad sufinanciran je projektom Hrvatske zaklade za znanost HRZZ-IP-2018-01-3844 Eugen Savojski (1663. - 1736.) i gradovi tvrđave jugoistočne granice Habsburške monarhije.

2

Plan je objavljen u: IVE MAŽURAN et al., Od turskog do suvremenog Osijeka, Osijek, 1996., 42, i SONJA GAĆINA - GRGUR MARKO IVANKOVIĆ, Planovi i vedute Osijeka, Osijek, 1996., 24.

3

STJEPAN SRŠAN, Zemljišna knjiga grada Osijeka (Tvrđa) 1687.1821. godine, Osijek, 1995., 5-9.

4

Izvornik u: Österreichisches Staatsarchiv - Kriegsarchiv, Inland A-III, No 1, 1828.

5

IVE MAŽURAN, Srednjovjekovni i turski Osijek, Osijek, 1994., $208,222$.

6

NENAD MOAČANIN, Osmanski Osijek: novi pristup, $\mathrm{Rad} \mathrm{Hr}$ vatske akademije znanosti i umjetnosti, 525 (2016.), 101.

7

NENAD MOAČANIN (bilj. 6), 92, izneseno prema opisu Evlije Čelebije.

8

IVE MAŽURAN, Grad i tvrđava Osijek, Osijek, 2000., 44, 45.

9

IVE MAŽURAN (bilj. 8), 50.

10

Isto, 53.

11

STJEPAN SRŠAN, Povijest Osijeka, Osijek, 1996., 59., 60.

12

IVE MAŽURAN, Urbanistički razvoj i spomenički značaj osječke Tvrđe, Osijek, 1974., 14; BLAŽO MISITA KATUŠIĆ, Kratak pregled arhitekture Osijeka kroz tri stoljeća, Osječki zbornik, 5 (1957.), 171-185; IVE MAŽURAN et al. (bilj. 2), 22; BOŽICA VALENČIĆ, Stara gradska vijećnica u osječkoj Tvrđi, Osječki zbornik, 27 (2004.), 167.

13

Usp. BOŽICA VALENČIĆ (bilj. 11), 170, 177; IVANA HANIČAR BULJAN - RATKO VUČETIĆ, Konzervatorska podloga bloka Trg sv. Trojstva - Bösendorfferova - Franjevačka - Kuhačeva u osječkoj Tvrdi: Blok 3, Institut za povijest umjetnosti, Zagreb, 2018., 65-66.

14

IVE MAŽURAN et al. (bilj. 2), 30.

15

KATARINA HORVAT-LEVAJ - MARGARETA TURKALJ PODMANICKI, Palača Slavonske Generalkomande u Osijeku, Zagreb - Osijek, 2019., 82, 83, 105-119.

16

Isto, 93.

17

Prvotno vlasništvo Čerkića može se odrediti prema napisu na mađarskom planu grada iz 1733. godine. Iako je kuća prodana
Antunu Planku 1759. godine, što može značiti da je tom prilikom i obnovljena, oblikovanje prostora u glavnini upućuje na nastanak početkom 18. stoljeća. Usp. STJEPAN SRŠAN (bilj. 3), 53-54.

18

STJEPAN SRŠAN (bilj. 3), 10-12; BOŽICA VALENČIĆ (bilj. 12), 158-162; IVANA HANIČAR BULJAN - RATKO VUČETIĆ (bilj. 13), 74-105. Kuća je dograđena s dvorišne strane u 19. stoljeću.

19

STJEPAN SRŠAN (bilj. 3), 42-43; VILIM MATIĆ, Povijest deset zgrada u osječkoj Tvrđi: Blok Kuhačeva ulica, Boškovićeva ulica, Markovićeva ulica i Firingerova ulica, Anali Zavoda za znanstveni i umjetnički rad u Osijeku, 17 (2001.), 55-58; IRENA PAUK SILI - PETAR PUHMAJER, Osijek. Markovićeva 1. Elaborat konzervatorsko-restauratorskih istraživanja pročelja, Hrvatski restauratorski zavod, Osijek, 2021.

20

Usp. STJEPAN SRŠAN (bilj. 3), 43-44; VILIM MATIĆ (bilj. 19), 52-55. IVANA HANIČAR BULJAN - RATKO VUČETIĆ, Konzervatorska podloga bloka Trg sv. Trojstva - Kuhačeva - Markovićeva - Firingerova - Boškovićeva u osječkoj Tvrdi: Blok 5, Institut za povijest umjetnosti, Zagreb, 2018., 67. Na planu grada iz 1733. ovdje se nalaze dvije kuće, a čini se da je njihovim objedinjavanjem definirana današnja prostorna osnova. Kuća ukazuje na izrazitu građevnu slojevitost. Usp. IVAN SRŠA, Izvještaj o rezultatima konzervatorsko-restauratorskih istraživanja na pročeljima kuća u osječkoj Tvrđi u Kuhačevoj ulici br. 11, 13 i 15, Hrvatski restauratorski zavod, Zagreb, 2001., 108-111.

21

Kuća je sagrađena na mjestu dviju ranijih kuća od kojih je jedna pripadala obitelji Pejačević, a kupio ih je Josip Bittner i sagradio današnju. VILIM MATIĆ (bilj. 19), 59-61. Već tijekom druge polovine 18. stoljeća, a svakako prije 1828. glavnom su krilu kuće nadograđena dva dvorišna krila. U 19. stoljeću kuća je kompletno preoblikovana u neobaroknom stilu za obitelj Salopek. Usp. IVAN SRŠA (bilj. 20), 79-80.

22 VILIM MATIĆ (bilj. 19), 62-63; IVAN SRŠA (bilj. 20), 56-57, 60-61; IVANA HANIČAR BULJAN - RATKO VUČETIĆ (bilj. 20), 99.

23 Nacionalna i sveučilišna knjižnica, Zagreb (dalje: NSK), Zbirka planova i nacrta osječke Tvrđe, XI-SK-J-114, Plan des Brigade Haus mit jenen Herstellungen welche nöthig sind um dasselbe zur Unterkunft des Truppen Divisionärs geeignet zu machen, 1850.

24

Dataciju gradnje možemo po prilici odrediti prema podatcima iz Zemljišne knjige 1747./1748. godine u kojoj se »novosagrađena kuća spominje kao vlasništvo trgovca Mihovila Kostića koji ju je »obnovio od temelja«, usp. STJEPAN SRŠAN (bilj. 3), 52-53.

25

NSK, Zbirka planova i nacrta osječke Tvrđe, XI-SK-J-123, Plan Litt. D von dem zu verkaufen komenden Bürgerlichen sogenandten Costiczischen Haus in der Festung Esseg, autor: G. Tomerlin, 1774. O nacrtu i preseljenju generalova stana iz Generalkomande vidjeti: KATARINA HORVAT-LEVAJ - MARGARETA TURKALJ PODMANICKI (bilj. 17), 96-97. 
26

KATARINA HORVAT-LEVAJ - RATKO VUČETIĆ - GORAN VAREŠKO, Konzervatorska studija sa smjernicama za obnovu kuće u ulici Franje Kuhača 23 u osječkoj Tvrdi, Institut za povijest umjetnosti, Zagreb, 2017.

27

NSK, Zbirka planova i nacrta osječke Tvrđe, XI-SK-J-126, Plan Litt. E, Entwurf über die vermäge hoher Genie Haupt Amts Verordnung, autori: Petrasch, Haggenmüller, 1839. i XI-SK-J-110, Entwurf über die Verschallung des Bogenganges..., autor: Libaschinsky, 1839. Nije utvrđeno vrijeme uklanjanja arkada i zidanja hodnika s velikim prozorima, no to se moralo dogoditi u drugoj polovini 19. stoljeća.

28

Na povijesnoj fotografiji Juliusa Exnera iz 1877. vidi se izvorno oblikovanje pročelja. Muzej Slavonije Osijek, Zbirka fotografija, br. 175228.

29

Datacija se može po prilici odrediti prema vremenu spajanja dviju starijih kuća 1768. godine, koje su tada pregrađene ili dijelom porušene. STJEPAN SRŠAN, Zapisnik općine Osijek-Tvrđa od 1745. do 1770. godine, Osijek, 1987., 336. Zemljišna knjiga iz 1747. - 1748. godine bilježi na tom mjestu kuću Marges (sjeverno) i Farkaš (južno). Na mađarskom planu grada iz 1733. godine njihov je položaj zamijenjen. Krajem stoljeća vlasnik jedinstvene kuće je poreznik Ritter, zatim Nikola Cambesy 1815., a 1840. udovica Ana Kovačević koja ne stanuje u kući. Godine 1898. pridružena je i sjeverno smještena susjedna kuća te je cijeli sklop pregrađen za biskupsko sjemenište prema projektu arhitekta Josipa Vancaša. Usp. STJEPAN SRŠAN (bilj. 3), 60, 61, 81, 83, 85; MILKO PUNCER, Konzervatorska studija za interpolaciju dvorane Glazbene škole u Tvrdi, Osijek, 1991., 7-9.

30

NSK, Zbirka planova i nacrta osječke Tvrđe, XI-SK-J-111, Plan des Hauses N. 20. auf dem Parade Platze, autor: Franz Fux, 1853.

31

STJEPAN SRŠAN (bilj. 3), 52-53.

32

PETAR PUHMAJER, Gradska stambena arhitektura baroka, u: Slavonija, Baranja i Srijem: vrela europske civilizacije (ur. Vesna Kusin - Branka Šulc), svezak II, Zagreb, 2009., 358-365.

33

Isto, 358.

34

Inženjer Johann Friedrich von Heysse spominje se kod gradnje Glavne straže, ugarski arhitekt Janos Hölbling kao projektant Velike oružane, a među vojnim graditeljima moralo bi se nalaziti i ime zasad još nepoznatog projektanta palače Generalkomande. IVE MAŽURAN et al. (bilj. 2); MARGARETA TURKALJ PODMANICKI - KATARINA HORVAT-LEVAJ, Nekadašnja isusovačka crkva sv. Mihovila u Osijeku u srednjoeuropskom kontekstu, Peristil, 54 (2011.), 223-233; KATARINA HORVAT-LEVAJ MARGARETA TURKALJ PODMANICKI (bilj. 15), 136-143.

35

PETAR PUHMAJER, Žbukani i naslikani medaljoni - prilog razvoju pročelja 17. i 18. stoljeća u kontinentalnoj Hrvatskoj, Portal, 7 (2016.), 221.

36

IVAN SRŠA, Pročelja kuće Streicher u osječkoj Tvrđi, Godišnjak zaštite spomenika kulture Hrvatske, 22/23 (1996.-1997.), 159, 162.

37

IVAN SRŠA (bilj. 20), 58, 108-109.

38

PETAR PUHMAJER, Odraz ugarske graditeljske radionice Andreasa Mayerhoffera u stambenoj arhitekturi Osijeka u 18. stoljeću, Radovi Instituta za povijest umjetnosti, 37 (2013.), 139; DRAGAN DAMJANOVIĆ, The Hatzinger Family of Builders From Székesfehérvár, through Osijek, Lviv, and Zadar to Vienna, Acta Historiae Artium, 57 (2016.), 168-169. O vlasničkoj povijesti kuće: VILIM MATIĆ (bilj. 19), 45-48.

39

IVY LENTIĆ KUGLI, Prilog istraživanju osječkih graditelja 18. stoljeća, Vijesti muzealaca i konzervatora Hrvatske, 1 (1973.), 12; ĐURĐICA CVITANOVIĆ, Palača Srijemske županije u Vukovaru, Radovi Instituta za povijest umjetnosti, 22 (1998.), 111-113.

40

PETAR PUHMAJER (bilj. 35), 222.

41

PETAR PUHMAJER (bilj. 38), 130, 139.

42

Isto, 133-139.

43

Na kući Pejačević-Niczky (Markovićeva 1) žbukana je dekoracija bila većinom uklonjena, ali je fragmentarno rekonstruirana $\mathrm{u}$ obnovi krajem 20. stoljeća. Izvorno su se na plohama kata nalazili žbukani toskanski pilastri s profilacijom sličnom onoj na kućama Nikolantin i Ritter. IRENA PAUK SILI - PETAR PUHMAJER (bilj. 19).

44

Na kući Ritter (Trg sv. Trojstva 1) je izvedena neobarokna dekoracija prema projektu Josipa Vancaša, ali su na pročelju prema Kuhačevoj ulici zadržani izvorni toskanski pilastri iz 18. stoljeća. 


\section{Summary}

\section{Petar Puhmajer - Ratko Vučetić - Ivana Haničar Buljan \\ Civil Architecture in $18^{\text {th }}$-Century Osijek Tvrđa: Houses of Merchants and Artisans}

The article discusses spatial and design features of Osijek's residential architecture in the $18^{\text {th }}$ century. The authors focus on the higher-standard houses erected on plots within Osijek's planned city fortress, Tvrđa, as well as the time of their construction and the investors. These mostly included artisans, merchants, city and military officials. They used the houses for trade, which took place in the ground-floor shops, while the living quarters of the owners were located on the first floor. The floor plans were organized in rows or groups of rooms. The ground floor had a porte-cochère, either centred or decentred with regard to the central axis, and several other vaulted rooms grouped around or aligned to it. The first-floor living quarters had a group of rooms, the largest usually being a drawing room. Although smaller in scale, the houses resembled the public and military buildings in Tvrđa, both in their floor-plan organization and in the design of their front façades, since the designers were the same - military engineers engaged in the construction of the fortress.

Keywords: civil architecture, residential architecture, housing, Osijek, $18^{\text {th }}$ century, houses, floor plan, façade 